\title{
Combined Starter Phosphorus and Manure Applications on Silage Corn Yield and Phosphorus Uptake in Southern BC
}

\author{
Aimé J. Messiga*, Camellia Lam, Yunkun Li, Steven Kidd, Shaobing Yu and \\ Carine Bineng
}

Agassiz Research and Development Centre, Agriculture and Agri-Food Canada, Agassiz, BC, Canada

\section{OPEN ACCESS}

Edited by:

Paulo Sergio Pavinato, University of São Paulo, Brazil

Reviewed by:

Sudipta Rakshit,

Tennessee State University,

United States

Gonzalo Ferreira,

Virginia Tech, United States

*Correspondence:

Aimé J. Messiga

aime.messiga@canada.ca

Specialty section:

This article was submitted to

Soil Processes,

a section of the journal

Frontiers in Earth Science

Received: 13 January 2020

Accepted: 13 March 2020

Published: 07 April 2020

Citation:

Messiga AJ, Lam C, Li Y, Kidd S,

Yu S and Bineng C (2020) Combined

Starter Phosphorus and Manure

Applications on Silage Corn Yield

and Phosphorus Uptake in Southern

BC. Front. Earth Sci. 8:88

doi: 10.3389/feart.2020.00088
Phosphorus $(\mathrm{P})$ management using mineral and manure $\mathrm{P}$ in excess of plant needs contributes to legacy soil $\mathrm{P}$ in coastal British Columbia, Canada. The objectives of this study were (a) to assess the effects of starter $\mathrm{P}$ at early growth stages and their carryover through corn maturity, and (b) to determine how corn yields relate to soil $\mathrm{P}$ saturation indicators. Eleven 1-year experiments were conducted on sites with contrasting legacy soil $P$ in 2018 (three sites) and 2019 (eight sites). Six combinations of starter and manure $\mathrm{P}$ rates $\left(\mathrm{T} 1: \mathrm{OP}_{\text {starter }}+\mathrm{OP}_{\text {manure }}\right.$; $\mathrm{T} 2: \mathrm{OP}_{\text {starter }}+35 \mathrm{P}_{\text {manure }} ; \mathrm{T} 3: 5 \mathrm{P}_{\text {starter }}+30 \mathrm{P}_{\text {manure}}$; T4: $10 \mathrm{P}_{\text {starter }}+25 \mathrm{P}_{\text {manure }} ; \mathrm{T} 5: 15 \mathrm{P}_{\text {starter }}+20 \mathrm{P}_{\text {manure }}$; T6: 20P $\left.\mathrm{P}_{\text {starter }}+15 \mathrm{P}_{\text {manure }}\right)$ were assigned to a RCBD with four replicates. In 2018, corn dry matter weight (DMY) at the 6-leaf stage was affected by starter $P$ in all sites, and the response curve was described by a linear-plus-plateau model with critical starter $P$ of 5.0 and $7.5 \mathrm{~kg} \mathrm{ha}^{-1}$. In 2019, corn DMY at early growth stages was not affected by starter P. Corn DMY at harvest varied between $15.2 \mathrm{Mg} \mathrm{ha}^{-1}$ in sites with low initial soil $\mathrm{P}$ and $27.2 \mathrm{Mg}$ $\mathrm{ha}^{-1}$ in sites with excess $\mathrm{P}$. Four sites exhibited a trend of high DMY with treatment comprising low starter $\mathrm{P}$ and high side-dressed manure $\mathrm{P}$ additions. The degree of $\mathrm{P}$ saturation (DPS, 14.0 to $38.0 \%$ ) and $\mathrm{P}$ saturation index (PSI, 3.0 to $14.0 \%)$ were related to corn DMY by quadratic functions $\left(R^{2}=0.76-0.94\right)$. From these results, we can conclude that the effect of starter $\mathrm{P}$ on young corn plants varies with year, but does not carryover through harvest. Moreover, current starter $\mathrm{P}\left(30-40 \mathrm{~kg} \mathrm{ha}^{-1}\right)$ recommended for corn can be reduced by up to $75 \%\left(5.0-7.5 \mathrm{~kg} \mathrm{ha}^{-1}\right)$ without affecting yield, thus reducing annual $P$ inputs and farmers' production costs. Finally, PSI as a proxy of DPS is a possible agro-environmental indicator that, coupled with reduced starter $P$ fertilizer, can further contribute to reducing the risk of $\mathrm{P}$ transfer from agricultural soils in coastal British Columbia.

Keywords: starter $\mathbf{P}$ fertilizer, manure $\mathrm{P}$, silage corn yield, 3- and 6-leaf stage, legacy soil $\mathrm{P}, \mathrm{P}$ saturation index

\section{INTRODUCTION}

In coastal British Columbia (BC), Canada, agricultural soils receive large annual phosphorus (P) inputs including dairy and poultry manures as well as chemical fertilizers to support a diverse and intensive peri-urban agricultural sector. A provincial soil survey conducted in 2007 showed that $89 \%$ of fields have soil test $\mathrm{P}$ concentrations varying between 100 and 350 mg Mehlich-3 P ( $\left.\mathrm{P}_{\mathrm{M} 3}\right)$ 
$\mathrm{kg}^{-1}$, which increases the risk of $\mathrm{P}$ transport by runoff (Kowalenko et al., 2007). A national study using the indicator of risk of water contamination by $\mathrm{P}$ showed that 35 to $75 \%$ of croplands in Abbotsford (largest city in Fraser Valley) have P source concentrations above the environmental threshold of $4 \mathrm{mg}$ $\mathrm{P} \mathrm{kg}^{-1}$ (van Bochove et al., 2012). Heavy rainfalls in these areas, mostly during the non-growing season, and the relatively dry summers also increase the risk of $\mathrm{P}$ loss by preferential flow. Reports have shown that the Fraser and Sumas Rivers fit in the Eutrophic class with total P concentrations between 30 and $100 \mathrm{mg} \mathrm{L}^{-1}$ (British Columbia Ministry of Environment, 2006). It is crucial to disentangle the mechanisms controlling P cycling (input, transformation, and output) in these soils with high legacy $\mathrm{P}$ concentrations.

Silage corn (8500 ha) and forage grass (13,670 ha) rotation is the main cropping system providing feed for dairy cows in BC. Phosphorus fertilization recommendations for the silage corn phase of the rotation averaged $90 \mathrm{~kg} \mathrm{P} \mathrm{ha}^{-1}$, including $50 \mathrm{~kg} \mathrm{P}$ $\mathrm{ha}^{-1}$ as dairy manure and $40 \mathrm{~kg} \mathrm{P} \mathrm{ha}^{-1}$ as starter fertilizer $\mathrm{P}$ for a crop that exports on average $35 \mathrm{~kg} \mathrm{P} \mathrm{ha}^{-1}$ (Bittman et al., 2006; Zhang et al., 2018). The annual P surplus for forage grass and silage corn rotation systems is $3030 \mathrm{Mg}\left(50 \mathrm{~kg} \mathrm{P} \mathrm{ha}{ }^{-1}\right)$ (Bittman et al., 2017), which contributes to buildup of legacy soil P. A better match of $\mathrm{P}$ applications to silage corn needs is necessary to maintain or drawdown legacy soil $\mathrm{P}$.

Starter $\mathrm{P}$ is a small amount of $\mathrm{P}$ fertilizer placed in close proximity to the seed at planting to promote young plants' growth until the root system develops. Starter P fertilizer rates are 5 to $15 \mathrm{~kg} \mathrm{P} \mathrm{ha}{ }^{-1}$ in Ontario and Quebec (Preston et al., 2019), and 5 to $13 \mathrm{~kg} \mathrm{P} \mathrm{ha}^{-1}$ in the US (Jokela, 1992). The placement or banding of $\mathrm{P}$ fertilizer near the seed reduces $\mathrm{P}$ fixation because soil-fertilizer contact is limited, making more $\mathrm{P}$ available to young plants soon after germination (Jokela, 1992). The benefits of starter fertilizer P on early growth of corn are well-recognized, particularly in low-P soils (Wolkowski, 2000; Vetsch and Randall, 2002; Preston et al., 2019). In areas where cool soil temperatures prevail early in the growing season, starter $\mathrm{P}$ can be beneficial even in high-P soils (Bittman et al., 2006). While some studies show the lasting effects of starter $\mathrm{P}$ through harvest (Bordoli and Mallarino, 1998; Malhi et al., 2001; Preston et al., 2019), other have highlighted the fact that early growth and nutrient uptake responses to starter $\mathrm{P}$ do not always translate into higher yield (Randall and Hoeft, 1988; Mallarino et al., 1999). The carryover of starter P effects through maturity was also observed primarily on a low-P soil (Bordoli and Mallarino, 1998). In Wisconsin, corn yield response to starter $\mathrm{P}$ was not observed on an excessively high-testing silt loam soil (Wolkowski, 2000).

Over the past two decades, extensive research has been conducted to develop or adapt agri-environmental $\mathrm{P}$ risk indicators to assess the risk of $\mathrm{P}$ loss from agricultural soils (Renneson et al., 2015). The P saturation index (PSI) as adaptation of the degree of $\mathrm{P}$ saturation (DPS) using routine agronomic soil test was developed in several agricultural regions of Canada and the United States. A PSI was adapted for the acidic soils of eastern Canada (Khiari et al., 2000; Pellerin et al., 2006; Benjannet et al., 2018) and the mid-Atlantic regions of the US (Sims et al., 2002) using $\mathrm{P}$ and Aluminum (Al) extracted by the
Mehlich-3 method because $\mathrm{P}$ retention is correlated with $\mathrm{Al}$ in these soils. Benjannet et al. (2018) identified two critical values of PSI for Atlantic Canada above which P fertilization should be limited to crop requirements: $19.2 \%$ for very to extremely acidic soils ( $\mathrm{pH}<5.5)$ and $14.2 \%$ for slightly to moderately acidic soils $(\mathrm{pH}>5.5)$. Pellerin et al. (2006) reported two critical PSI values for Quebec of 13.1 and 7.6\% for coarse- and fine-textured soils, respectively. Given the differences observed on PSI values across areas and the influence of factors such as $\mathrm{pH}$ and soil textures, it is crucial to understand how these indicators of $\mathrm{P}$ risk relate to classical agronomic parameters before suggesting its use for the high legacy $\mathrm{P}$ soils of $\mathrm{BC}$. The objectives of this study were (a) to assess the effects of starter fertilizers $\mathrm{P}$ at early growth stages (3- and 6-leaf stages) and their carryover through silage corn maturity, and (b) to determine how silage corn yields relate to soil $\mathrm{P}$ saturation indicators in high legacy soil $\mathrm{P}$ environments.

\section{MATERIALS AND METHODS}

\section{Site Description}

A 2-year study was conducted in 2018 and 2019 in Agassiz and Rosedale, located in south coastal BC, Canada. Three sites were selected in 2018 and eight sites in 2019, for a total of 11 1-year corn trials (site1-site11). Soils in the area include the Monroe series, characterized by a feeble profile development and coarse texture (Typic Dystroxerepts under the U.S. Soil Taxonomy; Soil Survey Staff, 2014). The minimum and maximum general soil properties across all sites were: soil pH: 4.9 and 6.0; total carbon: 0.94 and $11.35 \%$; total nitrogen: 0.07 and $0.82 \%$; and Mehlich-3 extractable P: 3.42 and $195.32 \mathrm{mg} \mathrm{kg}^{-1}$ (Table 1). The average daily temperature ranges from $3.2^{\circ} \mathrm{C}$ in December to $18.8^{\circ} \mathrm{C}$ in August. The local climate is moderate oceanic, characterized by warm, rainy winters and relatively cool, dry summers with annual rainfall of $1689 \mathrm{~mm}, 261.9 \mathrm{~mm}$ of which falls between May and July (Table 2).

TABLE 1 | Minimum and maximum values of general properties of soils $(0-15 \mathrm{~cm}$ depth) at 11 studied sites in 2018 and 2019.

\begin{tabular}{|c|c|c|c|c|}
\hline & \multicolumn{2}{|c|}{2018} & \multicolumn{2}{|c|}{2019} \\
\hline & Minimum & Maximum & Minimum & Maximum \\
\hline Number of samples & 12 & 12 & 28 & 28 \\
\hline $\mathrm{pH}_{\mathrm{H} 2 \mathrm{O}}$ & 5.3 & 5.7 & 4.9 & 6.0 \\
\hline Total Carbon (\%) & 0.94 & 3.42 & 1.44 & 11.35 \\
\hline Total Nitrogen (\%) & 0.07 & 0.31 & 0.16 & 0.82 \\
\hline $\mathrm{C}$ to $\mathrm{N}$ ratio & 9.65 & 13.10 & 8.84 & 14.28 \\
\hline Mehlich-3 P (mg kg-1) & 51.47 & 204.09 & 10.09 & 172.68 \\
\hline Mehlich-3 Al (mg kg-1) & 1413.93 & 1505.90 & 1103.66 & 3079.34 \\
\hline Mehlich-3 Fe $\left(\mathrm{mg} \mathrm{kg}^{-1}\right)$ & 139.85 & 281.51 & 172.76 & 424.54 \\
\hline Oxalate $\mathrm{P}\left(\mathrm{mg} \mathrm{L}^{-1}\right)$ & 26.42 & 82.14 & 11.10 & 69.08 \\
\hline Oxalate $\mathrm{Al}\left(\mathrm{mg} \mathrm{L}^{-1}\right)$ & 132.53 & 294.19 & 116.62 & 562.08 \\
\hline Oxalate $\mathrm{Fe}\left(\mathrm{mg} \mathrm{L}^{-1}\right)$ & 132.35 & 281.76 & 129.27 & 823.77 \\
\hline Kelowna P (mg kg $\left.{ }^{-1}\right)$ & 36.70 & 195.32 & 3.75 & 73.07 \\
\hline
\end{tabular}


TABLE 2 | Monthly total precipitations and mean monthly air and soil temperatures at Agassiz - Rosedale, BC, in 2018 and 2019 in comparison with the 30 -year (1981-2010) average.

\begin{tabular}{|c|c|c|c|c|c|c|c|c|}
\hline & \multicolumn{3}{|c|}{ Precipitation (mm) } & \multicolumn{3}{|c|}{ Air temperature $\left({ }^{\circ} \mathrm{C}\right)$} & \multicolumn{2}{|c|}{$\begin{array}{l}\text { Soil temperature at } \\
0-20 \mathrm{~cm} \text { depth }\left({ }^{\circ} \mathrm{C}\right)\end{array}$} \\
\hline & 2018 & 2019 & 30-year average & 2018 & 2019 & 30 -year average & 2018 & 2019 \\
\hline May & 23.3 & 41.0 & 103.0 & 16.5 & 16.0 & 13.6 & 19.9 & 18.2 \\
\hline June & 89.4 & 72.4 & 92.3 & 16.3 & 17.1 & 16.2 & 19.6 & 20.7 \\
\hline July & 30.3 & 64.4 & 66.6 & 20.7 & 18.8 & 18.5 & 23.8 & 22.8 \\
\hline August & 18.5 & 55.2 & 58.2 & 19.5 & 19.6 & 18.7 & 22.2 & 22.7 \\
\hline September & 134.9 & 172.2 & 87.6 & 15.4 & 16.0 & 15.9 & 17.7 & 17.6 \\
\hline Total & 296.4 & 405.2 & 407.7 & & & & & \\
\hline Average & & & & 17.7 & 17.5 & 16.6 & 20.6 & 20.4 \\
\hline
\end{tabular}

TABLE 3 | Description of the six combination of starter $P$ and manure $P$ treatments.

\begin{tabular}{|c|c|c|c|c|}
\hline Treatment combinations & $\begin{array}{l}\text { Starter P } \\
\left(\mathrm{kg} \mathrm{ha}^{-1}\right)\end{array}$ & $\begin{array}{l}\text { Manure available } \mathrm{P} \text { at } \\
\text { 6-leaf stage }\left(\mathrm{kg} \mathrm{ha}^{-1}\right)^{\mathrm{a}}\end{array}$ & $\begin{array}{c}\text { Total available P } \\
\left.\text { (kg ha }{ }^{-1}\right)\end{array}$ & $\begin{array}{c}\text { Total } \mathrm{N} \text { applied } \\
\left(\mathrm{kg} \mathrm{ha}^{-1}\right)^{\mathrm{b}}\end{array}$ \\
\hline $\mathrm{OP}_{\text {starter }}+\mathrm{OP}_{\text {manure }}$ & 0 & 0 & 0 & 150 \\
\hline $\mathrm{OP}_{\text {starter }}+35 \mathrm{P}_{\text {manure }}$ & 0 & 35 & 35 & 150 \\
\hline $5 P_{\text {starter }}+30 P_{\text {manure }}$ & 5 & 30 & 35 & 150 \\
\hline $10 \mathrm{P}_{\text {starter }}+25 \mathrm{P}_{\text {manure }}$ & 10 & 25 & 35 & 150 \\
\hline $15 \mathrm{P}_{\text {starter }}+20 \mathrm{P}_{\text {manure }}$ & 15 & 20 & 35 & 150 \\
\hline $20 \mathrm{P}_{\text {starter }}+15 \mathrm{P}_{\text {manure }}$ & 20 & 15 & 35 & 150 \\
\hline
\end{tabular}

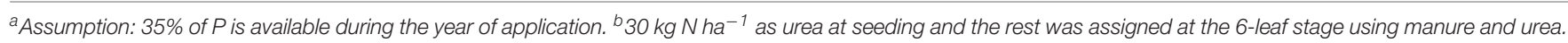

\section{Experimental Design and Treatments}

The 11 1-year corn experiments consisted of six treatments of combined starter fertilizer $\mathrm{P}$ and manure $\mathrm{P}$ rates. The six treatments were assigned to a randomized complete block design with four replicates for a total of 24 experimental units $(10 \mathrm{~m}$ long and $4.5 \mathrm{~m}$ wide). Starter fertilizer P rates were $0,0,5,10,15$, and $20 \mathrm{~kg} \mathrm{P} \mathrm{ha}^{-1}$ as triple super phosphate (TSP), and manure $\mathrm{P}$ rates were $0,15,20,25,30$, and $35 \mathrm{~kg}$ available $\mathrm{P} \mathrm{ha}^{-1}$. The six combinations of starter $\mathrm{P}$ (mineral fertilizer) and manure $\mathrm{P}$ treatments were arranged to meet a total available $\mathrm{P}$ input of $35 \mathrm{~kg} \mathrm{P} \mathrm{ha}{ }^{-1}$ as follows: T0: $0 \mathrm{P}_{\text {starter }}+0 \mathrm{P}_{\text {manure }}, \mathrm{T} 1: 0 \mathrm{P}_{\text {starter }}+$ $35 \mathrm{P}_{\text {manure }}, \mathrm{T} 2: 5 \mathrm{P}_{\text {starter }}+30 \mathrm{P}_{\text {manure }}, \mathrm{T} 3: 10 \mathrm{P}_{\text {starter }}+25 \mathrm{P}_{\text {manure }}$, T4: $15 \mathrm{P}_{\text {starter }}+20 \mathrm{P}_{\text {manure }}, \mathrm{T} 5: 20 \mathrm{P}_{\text {starter }}+15 \mathrm{P}_{\text {manure }}$ (Table 3).

The fields selected for the trials were sprayed with Roundup [glyphosate (N)-(phosphonomethyl)glycine, $1000 \mathrm{~g} \mathrm{ha}^{-1}$ ] to terminate the grass stand in early April. The soil was plowed to a depth of $30 \mathrm{~cm}$, followed by disking and harrowing to $10 \mathrm{~cm}$, and marked with flags to delineate the experimental plots before seeding in early to mid-May. There were six rows by plot unit, and corn was sown at $81 \times 10^{3}$ plants $\mathrm{ha}^{-1}$. Starter fertilizer N $\left(30 \mathrm{~kg} \mathrm{~N} \mathrm{ha}^{-1}\right)$ as urea $(46 \% \mathrm{~N})$ was band-applied ( $5 \mathrm{~cm}$ from the seeding row) using a disk opener ( $5 \mathrm{~cm}$ deep). Starter fertilizer P as TSP was band-applied by hand $(5 \mathrm{~cm}$ from the seeding row) and buried (5 $\mathrm{cm}$ deep) with a rake the day following planting. Additions of manure $\mathrm{P}\left(0,35 ; 30 ; 25 ; 20\right.$; and $15 \mathrm{~kg}$ available $\left.\mathrm{P} \mathrm{ha}^{-1}\right)$ to reach the target of $35 \mathrm{~kg}$ available $\mathrm{P} \mathrm{ha}^{-1}$ (we assumed that $35 \%$ of manure $\mathrm{P}$ is available during the year of application) and a supplement of $\mathrm{N}$ fertilizer as ammonium nitrate to meet the local recommendation of $150 \mathrm{~kg} \mathrm{~N}^{-1}$ (including manure $\mathrm{N})$ were side dressed at the 6-leaf stage to supply $\mathrm{P}$ and $\mathrm{N}$ for the rest of the growing season. The volume of manure for each combination treatment was measured in 11-L buckets and hand applied closed to the corn rows. Manure used in the corn experiments was collected in three dairy farms in the Frazer valley and their general chemical characteristics are presented in Table 4. At the 3-leaf stage, a mixture of post-emergence herbicides atrazine $\left(1353 \mathrm{~g} \mathrm{ha}^{-1}\right)$ and related triazines $\left(87 \mathrm{~g} \mathrm{ha}^{-1}\right)$ [2-chloro-4-ethylamino-6-isopropylamino1,3,5-trithemazine; 2-chloro- $\mathrm{N}$-(2-ethyl-6-methylphenyl)- $\mathrm{N}$ (2-methoxy-1-methyl-ethyl)-(S)] and glyphosate (1000 g $\mathrm{ha}^{-1}$ ) was sprayed to control weeds according to provincial recommendations (BC MA, 2012).

TABLE 4 | Average chemical characteristics of manure from three sources used in the corn experiments.

\begin{tabular}{lccc}
\hline & Source1 & Source2 & Source $^{\mathbf{b}^{\mathbf{}}}$ \\
\hline Dry matter (\%) & $2.75(0.24)^{\mathrm{a}}$ & $11.85(0.18)$ & 3.2 \\
Total nitrogen (\%) & $0.12(0.01)$ & $0.48(0.01)$ & 0.21 \\
$\mathrm{NH}_{4}-\mathrm{N}(\mathrm{ppm})$ & $665(80.73)$ & $1957.75(44.26)$ & 955 \\
Total phosphorus (\%) & $0.03(0.00)$ & $0.10(0.01)$ & 0.04 \\
Phosphate (\%P as $\left.\mathrm{P}_{2} \mathrm{O}_{5}\right)$ & $0.06(0.01)$ & $0.24(0.01)$ & 0.10 \\
Total potassium (\%) & $0.13(0.02)$ & $0.33(0.02)$ & 0.18 \\
Potash (\% $\mathrm{K}$ as $\left.\mathrm{K}_{2} \mathrm{O}\right)$ & $0.16(0.02)$ & $0.40(0.03)$ & 0.22 \\
\hline
\end{tabular}

a Values in parenthesis are standard deviations of the mean $(n=4) .{ }^{b}$ Manure from source3 was analyzed without replicates. 


\section{Plant Sampling and Measurements}

Corn plants were harvested at the 3-leaf stage (early-June), the 6-leaf stage (early-July), and maturity (mid-September) in a staggered pattern on the four innermost rows of each experimental plot. For the 3- and 6-leaf stages, 10 young corn plants were harvested, while for mature corn, 20 plants were harvested at $10 \mathrm{~cm}$ above the soil surface using a machete. Fresh weight was recorded in the field, and plants were chopped and a sub-sample of approximately $500 \mathrm{~g}$ from each plot was scooped and dried at $60^{\circ} \mathrm{C}$ in a forced-draft oven for 3-5 days and ground (2-mm screen). Dried and ground samples of $0.1 \mathrm{~g}$ were digested using a fluxer (M4 Fluxer, Claisse) and analyzed as described by Kowalenko and Babuin (2014). Phosphorus concentrations were assessed with an Inductively Coupled Plasma Optical Emission Spectrometer (ICAP 7000 series, Thermo Scientific). The P offtake at each harvest was calculated by multiplying corn $\mathrm{P}$ concentration by dry matter weight (DMY).

\section{Soil Analyses}

Soils were analyzed for general properties. Briefly, $\mathrm{pH}$ was measured in distilled water with a $1: 2$ soil: water ratio (Hendershot et al., 1993). Total C and $\mathrm{N}$ were determined by dry combustion with a LECO CNS-1000 (LECO, Corp., St. Joseph, MI, United States). Mehlich-3 extractable $\mathrm{P}\left(\mathrm{P}_{\mathrm{M} 3}\right)$, aluminum $\left(\mathrm{Al}_{\mathrm{M} 3}\right)$ and iron $\left(\mathrm{Fe}_{\mathrm{M} 3}\right)$ were determined by shaking $2.5 \mathrm{~g}$ of soil with a $25 \mathrm{~mL}$ of Mehlich-3 solution ( $\mathrm{pH}$ 2.3) for 5 min (Mehlich, 1984). Acid ammonium oxalate extractable P (POx), aluminum (AlOx) and iron ( $\mathrm{FeOx})$ were determined according to Ross and Wang (1993). The concentrations of $\mathrm{P}_{\mathrm{M} 3}, \mathrm{Al}_{\mathrm{M} 3}$, $\mathrm{Fe}_{\mathrm{M} 3}, \mathrm{POx}, \mathrm{AlOx}$, and $\mathrm{FeOx}$ were assessed with an Inductively Coupled Plasma Optical Emission Spectrometer (ICAP 7000 series, Thermo Scientific).

The PSI was related to Mehlich-3 extracts as follows (Sims et al., 2002; Messiga et al., 2013):

$$
\mathrm{PSI}=(\mathrm{P} / \mathrm{Al})_{\mathrm{M} 3}
$$

where $\mathrm{P}_{\mathrm{M} 3}$ and $\mathrm{Al}_{\mathrm{M} 3}$ are quantified in Mehlich-3 extracts $\left(\mathrm{mg} \mathrm{kg}^{-1}\right)$.

The DPS was related to acid ammonium oxalate extracts as follows (Breeuwsma and Silva, 1992; Messiga et al., 2013):

$$
\mathrm{DPS}=\mathrm{POx} /(\mathrm{Al}+\mathrm{Fe}) \mathrm{Ox}
$$

where $\mathrm{POx}, \mathrm{AlOx}$, and $\mathrm{FeOx}$ are quantified in acid ammonium oxalate extracts $\left(\mathrm{mmol} \mathrm{kg}^{-1}\right)$.

\section{Statistical Analyses}

Data were tested for normality using SAS univariate procedure. Analysis of variance (ANOVA) for DMY and P uptake for corn at the 3- and 6-leaf stages was performed separately for each site using the PROC MIXED of SAS version 9.3 (SAS Institute, 2010) with blocks as random effects and P rate as fixed effects. When $\mathrm{P}$ rate was significant, contrast analysis was used to assess if the effect was linear or quadratic. Model selection was based on graphical and numerical methods by comparing $R^{2}$, lack of fit $\mathrm{F}$ tests (Cerrato et al., 1990), and residual sum of squares.
The linear model was described as follows:

$$
\mathrm{Y}=\mathrm{a}+\mathrm{bx}
$$

Where $\mathrm{Y}$ is the corn DMY $\left(\mathrm{Mg} \mathrm{ha}^{-1}\right)$ or $\mathrm{P}$ uptake $\left(\mathrm{kg} \mathrm{P} \mathrm{ha}^{-1}\right)$, $\mathrm{a}$ is the intercept, $\mathrm{b}$ is the linear coefficient, and $\mathrm{x}$ is the starter $\mathrm{P}$ rate $\left(\mathrm{kg} \mathrm{Pha}^{-1}\right)$.

The linear-plus-plateau model is described as follows:

$$
\begin{gathered}
Y=a+b x \text { if } x<x 0 \\
Y=P \text { if } x>x 0
\end{gathered}
$$

where $\mathrm{Y}$ is the corn DMY $\left(\mathrm{Mg} \mathrm{ha}^{-1}\right)$ or $\mathrm{P}$ uptake $\left(\mathrm{kg} \mathrm{P} \mathrm{ha}^{-1}\right)$, a is the intercept, $b$ is the linear coefficient, $x$ is the starter $P$ rate $(\mathrm{kg} \mathrm{P}$ $\mathrm{ha}^{-1}$ ), C is the critical starter rate of fertilization, which occurs at the intersection of the linear response and the plateau lines, and $\mathrm{P}$ is the plateau corn DMY $\left(\mathrm{Mg} \mathrm{ha}^{-1}\right)$ or $\mathrm{P}$ uptake $\left(\mathrm{kg} \mathrm{P} \mathrm{ha}^{-1}\right)$, a constant obtained by fitting the model to the data.

ANOVA for DMY and P uptake for corn at maturity was performed separately for each site using the PROC MIXED with blocks as random effects and $\mathrm{P}$ combination treatment as fixed effects. When P combination treatment was significant, differences among least square means (LSMEANS) for all treatment pairs were tested at a significance level of $P=0.05$. In addition, standard errors of mean (SEM) were calculated.

\section{RESULTS}

\section{Weather Conditions}

In 2018, the growing season, from May to September, received $111.3 \mathrm{~mm}$ less rainfall than the 30-year normal of $407.7 \mathrm{~mm}$ (Table 2). More specifically, May with $23.3 \mathrm{~mm}$, July with $30.3 \mathrm{~mm}$ and August with $18.5 \mathrm{~mm}$ rainfall were respectively at least 4,2 and 3 times drier than the 30 -year normal. In 2019, May with $41.0 \mathrm{~mm}$ and June with $72.4 \mathrm{~mm}$ rainfall were respectively 2.5 and 1.3 times drier than the 30 -year normal. The mean growing season air temperatures of $17.7^{\circ} \mathrm{C}$ for 2018 and $17.5^{\circ} \mathrm{C}$ for 2019 were higher than the 30 -year normal of $16.6^{\circ} \mathrm{C}$. In 2018 , the mean air temperature in June was similar to the 30 year normal of $16.2^{\circ} \mathrm{C}$, but June 2019 was warmer. The warm air temperatures of June 2019 were translated into warmer soil temperatures compare with June 2018. In particular, during the periods May 26 and June 26, there were 13 successive days with soil temperatures below $19^{\circ} \mathrm{C}$ in 2018 (Figure 1A), compared with only 5 days in 2019 (Figure 1B). In addition, there were 8 days with soil temperatures below $18^{\circ} \mathrm{C}$ in 2018 , but only 1 day in 2019. In brief, mean soil temperature between May 26 and June 26 was $1^{\circ} \mathrm{C}$ cooler in 2018 with $19.6^{\circ} \mathrm{C}$ than 2019 with $20.6^{\circ} \mathrm{C}$.

\section{Corn Dry Matter Yield}

Corn DMY at the 3-leaf stage was not affected by starter P fertilization in all 11 sites in 2018 and 2019 (Figure 2). Corn DMY at the 3-leaf stage was on average $0.070 \mathrm{Mg} \mathrm{ha}^{-1}$ in site1, site2, and site (Figure 2A); $0.17 \mathrm{Mg} \mathrm{ha}^{-1}$ in site4, site7, and site9 (Figure 2B); $0.28 \mathrm{Mg} \mathrm{ha}^{-1}$ in site10 and site11 (Figure 2B); $0.41 \mathrm{Mg} \mathrm{ha}^{-1}$ in site8 (Figure 2B); and $0.78 \mathrm{Mg} \mathrm{ha}^{-1}$ in site 5 and site6 (Figure 2B). 

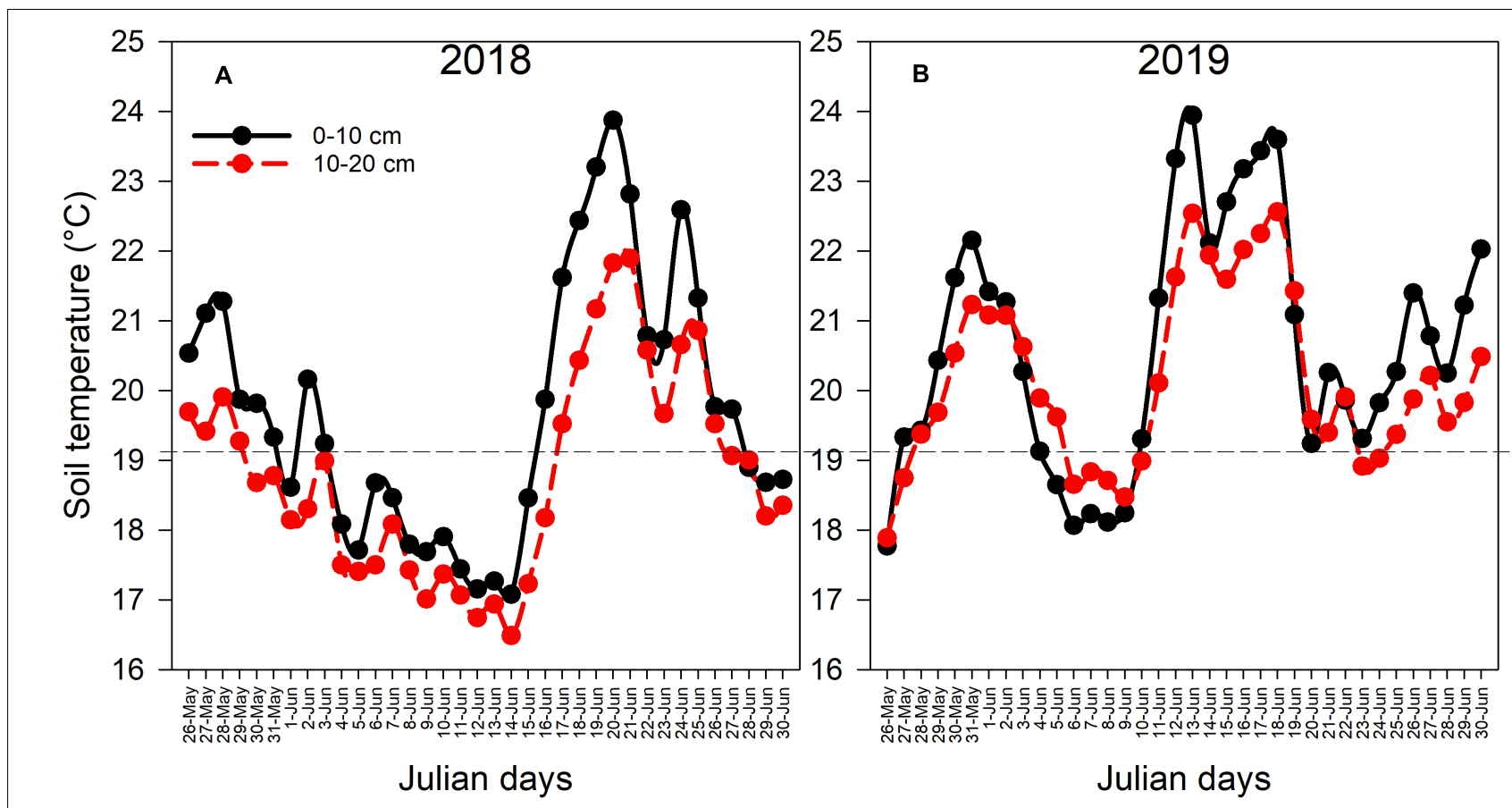

FIGURE 1 | Average soil temperature during the periods (A) May 26, 2018 and (B) May 26, 2019.

Corn DMY at the 6-leaf stage was affected by starter $\mathrm{P}$ fertilization in all three sites in 2018 (Figure 3A): site1 $(P$ value $=0.014)$, site2 $(P$ value $=0.033)$, and site3 $(P$ value $=0.032)$. The trend of corn DMY response across the three sites was described by a linear-plus-plateau model. The critical starter P rates were $5 \mathrm{~kg} \mathrm{ha}^{-1}$ for site 1 and site 3 and $7.5 \mathrm{~kg}$ $\mathrm{ha}^{-1}$ for site2. The plateau DMY were 0.39 and $0.37 \mathrm{Mg} \mathrm{ha}^{-1}$ for site 1 and site 3 and $0.66 \mathrm{Mg} \mathrm{ha}^{-1}$ for site2 (Table 5). In 2019, only six out of the eight sites were sampled at the 6-leaf stage due to workload and asynchrony with farmer's activities and planning. Corn DMY was not affected by starter P fertilization in the six sampled sites (Figure 3B). Corn DMY at the 6-leaf stage was on average $0.62 \mathrm{Mg} \mathrm{ha}^{-1}$ in site 9; $0.91 \mathrm{Mg} \mathrm{ha}^{-1}$ in site10 and site11; and $1.48 \mathrm{Mg} \mathrm{ha}^{-1}$ in site5, site6, and site8 (Figure 3B).

Corn DMY at harvest varied with starter and manure $\mathrm{P}$ additions in the three sites (site1, site2, site3) in 2018 and only one site (site11) in 2019 for a total of 4 out of 11 sites. Among the four sites, the highest corn DMY were obtained with treatment combinations comprising low banded starter $\mathrm{P}$ rates at planting and high side-dressed manure $\mathrm{P}$ additions at the 6-leaf stage. In site1, corn DMY was $18.60 \mathrm{Mg} \mathrm{ha}^{-1}$ with $\mathrm{T} 2\left(5 \mathrm{P}_{\text {starter }}+30 \mathrm{P}_{\text {Manure }}\right)$ and $15.15 \mathrm{Mg}$ ha $^{-1}$ with T5 (20 $\left.\mathrm{P}_{\text {starter }}+15 \mathrm{P}_{\text {Manure }}\right)$, representing a change of $22.75 \%$ (Figure $4 \mathrm{~A}$ ); in site2, corn DMY was $27.20 \mathrm{Mg}$ $\mathrm{ha}^{-1}$ with $\mathrm{T} 1\left(0 \mathrm{P}_{\text {starter }}+35 \mathrm{P}_{\text {Manure }}\right)$ and $22.75 \mathrm{Mg} \mathrm{ha}^{-1}$ with T5 $\left(20 \mathrm{P}_{\text {starter }}+15 \mathrm{P}_{\text {Manure }}\right)$, representing a change of 19.48\% (Figure 4A); in site3, corn DMY was $28.47 \mathrm{Mg} \mathrm{ha}^{-1}$ with $\mathrm{T} 2\left(5 \mathrm{P}_{\text {starter }}+30 \mathrm{P}_{\text {Manure }}\right)$ and $24.78 \mathrm{Mg} \mathrm{ha}^{-1}$ with $\mathrm{T} 4\left(15 \mathrm{P}_{\text {starter }}+20 \mathrm{P}_{\text {Manure }}\right)$ and $\mathrm{T} 0\left(0 \mathrm{P}_{\text {starter }}+0 \mathrm{P}_{\text {Manure }}\right)$, representing a change of $14.95 \%$ (Figure $\mathbf{4 A}$ ).

\section{Corn P Uptake}

Corn P uptake at the 3-leaf stage was affected by starter $\mathrm{P}$ fertilization in all three sites in 2018 (Figure 5A): site1 $(P$ value $=0.001)$, site2 $(P$ value $=0.003)$, and site3 $(P$ value $=0.021)$. The trend of corn $\mathrm{P}$ uptake response across the three sites was described by a linear-plus-plateau model. The critical starter $\mathrm{P}$ rates were $15 \mathrm{~kg} \mathrm{ha}^{-1}$ for sitel and site2 and $10 \mathrm{~kg} \mathrm{ha}^{-1}$ for site 3 . The plateau $\mathrm{P}$ uptake was $0.33 \mathrm{~kg}$ $\mathrm{ha}^{-1}$ for site 1 and site2 and $0.21 \mathrm{~kg} \mathrm{ha}^{-1}$ for site3 (Table 5). Corn $\mathrm{P}$ uptake at the 3-leaf stage was affected by starter $\mathrm{P}$ fertilization in only one site (site6) in 2019 (Figure 5B). Corn P uptake at the 3-leaf stage was on average $0.57 \mathrm{~kg} \mathrm{ha}^{-1}$ in site4, site7, and site10 (Figure 1B); $0.83 \mathrm{~kg} \mathrm{ha}^{-1}$ in site9 and site11 (Figure 1B); $1.53 \mathrm{~kg} \mathrm{ha}^{-1}$ in site8 (Figure 1B); and $3.44 \mathrm{~kg} \mathrm{ha}^{-1}$ in site6 (Figure 1B).

Corn $\mathrm{P}$ uptake at the 6-leaf stage was affected by starter $\mathrm{P}$ fertilization in all three sites in 2018 (Figure 6A): site1 $(P$ value $=0.001)$, site2 $(P$ value $=0.022)$, and site3 $(P$ value $=0.014)$. The trend of corn $\mathrm{P}$ uptake response across the three sites was described by a linear-plus-plateau model. The critical starter $\mathrm{P}$ rates were $7.5 \mathrm{~kg} \mathrm{ha}^{-1}$ for site 1 and $5.0 \mathrm{~kg}$ $\mathrm{ha}^{-1}$ for site 2 and site3. The plateau P uptakes were $1.63 \mathrm{~kg}$ $\mathrm{ha}^{-1}$ for site1, $2.05 \mathrm{~kg} \mathrm{ha}^{-1}$ for site2 and $1.06 \mathrm{~kg} \mathrm{ha}^{-1}$ for site 3 (Table 5). Corn P uptake at the 6-leaf stage was affected by starter P fertilization in only one site (site5) in 2019 (Figure 6B). Corn P uptake was on average $2.20 \mathrm{~kg} \mathrm{ha}^{-1}$ in site9 (Figure 6B); $3.67 \mathrm{~kg}$ $\mathrm{ha}^{-1}$ in site10 (Figure 6B); $4.22 \mathrm{~kg} \mathrm{ha}^{-1}$ in site11 (Figure 6B) and $5.12 \mathrm{~kg} \mathrm{ha}^{-1}$ in site5, site6, and site8 (Figure 6B).

Corn $\mathrm{P}$ uptake at harvest varied with starter and manure $\mathrm{P}$ additions in two sites (site1 and site2) out of three in 2018 and 


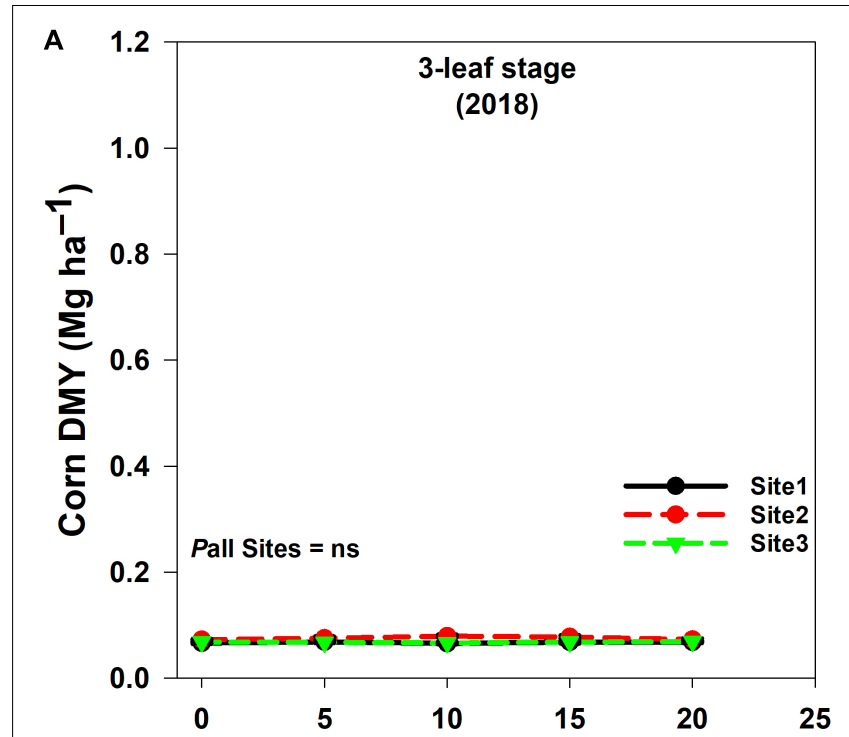

B

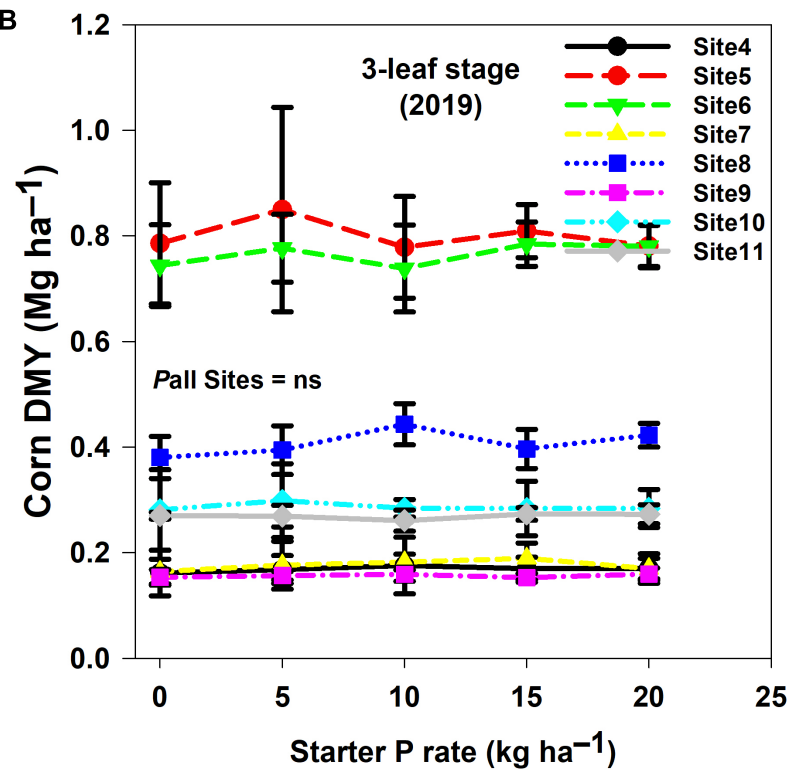

FIGURE 2 | Corn dry matter yield (DMY) at 3-leaf stage with application of starter $P$ rates across 11 sites [2018 (A) and 2019 (B)] in the Fraser Valley, BC. Error bars represent standard deviations of the means.

seven sites out of eight in 2019 (Figure 7). Corn P uptake varied between 19.66 and $29.79 \mathrm{~kg} \mathrm{ha}^{-1}$ in sitel (Figure 7A); 26.82 and $35.90 \mathrm{~kg} \mathrm{ha}^{-1}$ in site9 (Figure 7B); 28.17 and $37.24 \mathrm{~kg} \mathrm{ha}^{-1}$ in site7 (Figure 7B); 29.10 and $38.43 \mathrm{~kg} \mathrm{ha}^{-1}$ in site4 (Figure 7B); 55.67 and $63.54 \mathrm{~kg} \mathrm{ha}^{-1}$ in site 3 (Figure 7A); 56.67 and $73.46 \mathrm{~kg}$ $\mathrm{ha}^{-1}$ in site2 (Figure 7A); 57.00 and $68.63 \mathrm{~kg} \mathrm{ha}^{-1}$ in site11 (Figure 7B); 59.68 and $69.00 \mathrm{~kg} \mathrm{ha}^{-1}$ in site5 (Figure 7B); 61.18 and $70.29 \mathrm{~kg} \mathrm{ha}^{-1}$ in site8 (Figure 7B); 61.76 and $70.08 \mathrm{~kg} \mathrm{ha}^{-1}$ in site10 (Figure 7B); and 67.14 and $74.72 \mathrm{~kg} \mathrm{ha}^{-1}$ in site6 (Figure 7B). There was a trend of high corn $\mathrm{P}$ uptakes with treatment combinations comprising low banded starter $\mathrm{P}$ rates at planting and high side-dressed manure $\mathrm{P}$ additions at the 6-leaf stage, but low $\mathrm{P}$ uptake with treatment combinations comprising
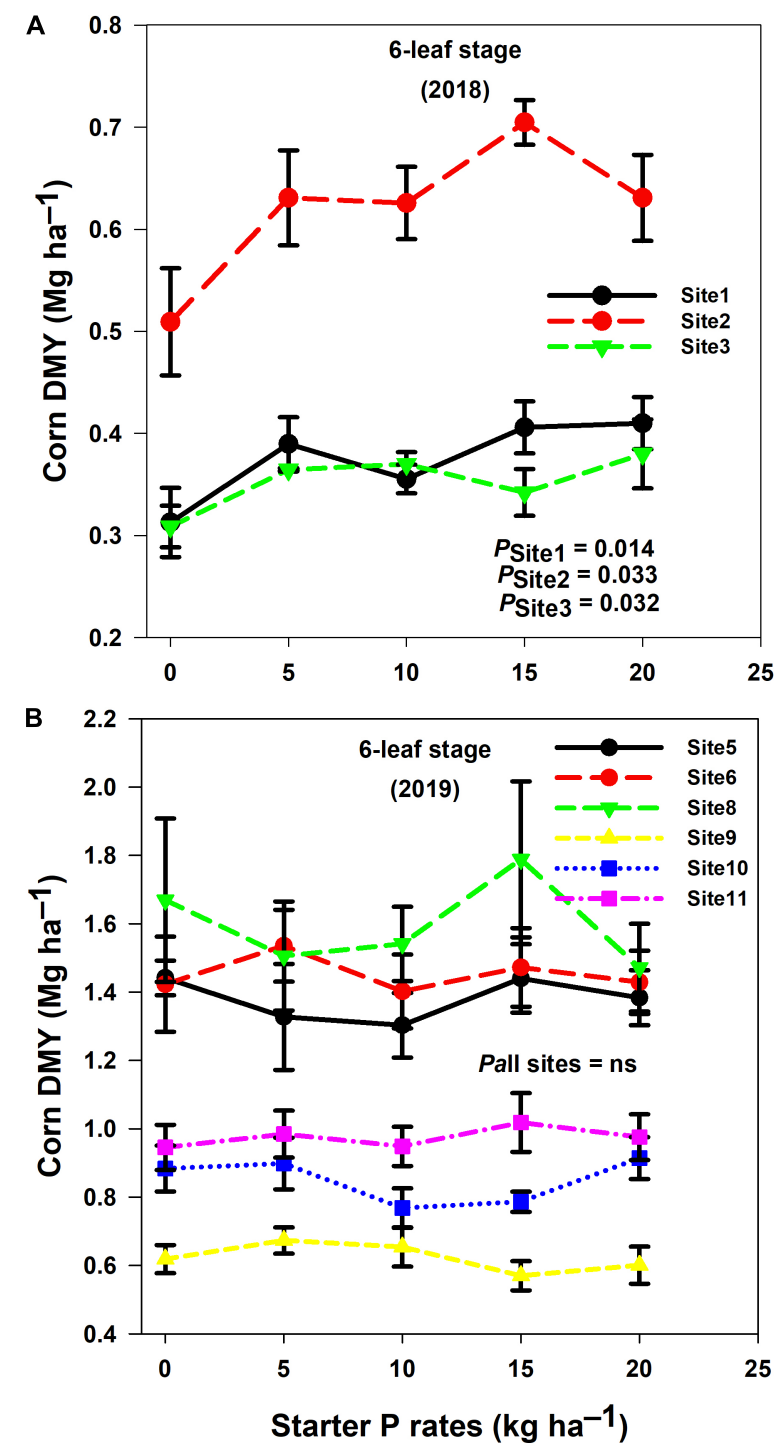

FIGURE 3 | Corn dry matter yield (DMY) at 6-leaf stage with application of starter P rates across 11 sites [2018 (A) and 2019 (B)] in the Fraser Valley, BC. Error bars represent standard deviations of the means.

high banded starter $\mathrm{P}$ rates at planting and low side-dressed manure $\mathrm{P}$ additions at the 6-leaf stage (Figure 7).

\section{Phosphorus Budget}

Phosphorus budget was significantly lower under control compared with the other starter and manure $\mathrm{P}$ combinations in all 11 sites in 2018 and 2019 (Figure 8). Phosphorus budget was on average $-31.26 \mathrm{~kg} \mathrm{ha}^{-1}$ in site1, site4, site7, and site9 (Figures $\mathbf{8 A}, \mathbf{B}$ ) and $-65.20 \mathrm{~kg} \mathrm{ha}^{-1}$ in the other sites (Figures 8A,B) with $0 \mathrm{P}$ addition. In contrast, phosphorus budget was on average $4.2 \mathrm{~kg} \mathrm{ha}^{-1}$ in site1, site4, site7 and site9 (Figures $\mathbf{8 A}, \mathbf{B}$ ) and $-29.73 \mathrm{~kg} \mathrm{ha}^{-1}$ in the other sites (Figures $\mathbf{8 A , B}$ ) with the different starter and manure $\mathrm{P}$ combinations. 
TABLE 5 | Parameters of the linear-plus-plateau response curves $(Y=b x+a)$ to $P$ fertilization of corn dry weight at the 6-leaf stage, corn $P$ uptake at the 3-and 6-leaf stages in 2018.

\begin{tabular}{|c|c|c|c|c|c|c|}
\hline & b & $\mathbf{a}$ & C & $\mathbf{P}$ & $P$-value & MSE \\
\hline Dry weight & \multicolumn{6}{|c|}{ (6-leaf stage) } \\
\hline Site1 & $0.016(0.006)$ & $0.313(0.026)$ & 5.0 & 0.39 & 0.014 & 0.011 \\
\hline Site2 & $0.019(0.008)$ & $0.514(0.052)$ & 7.5 & 0.66 & 0.033 & 0.024 \\
\hline Site3 & $0.011(0.005)$ & $0.310(0.021)$ & 5.0 & 0.37 & 0.032 & 0.009 \\
\hline P uptake & \multicolumn{6}{|c|}{ 3-leaf stage } \\
\hline Site1 & $0.0067(0.001)$ & $0.239(0.016)$ & 15.0 & 0.339 & 0.001 & 0.008 \\
\hline Site2 & $0.0052(0.002)$ & $0.248(0.016)$ & 15.0 & 0.326 & 0.003 & 0.008 \\
\hline Site3 & $0.003(0.001)$ & $0.179(0.011)$ & 10.0 & 0.214 & 0.021 & 0.005 \\
\hline P uptake & \multicolumn{6}{|c|}{ 6-leaf stage } \\
\hline Site1 & 0.079 (0.019) & $1.031(0.119)$ & 7.5 & 1.630 & 0.001 & 0.054 \\
\hline Site2 & $0.105(0.042)$ & $1.520(0.187)$ & 5.0 & 2.050 & 0.022 & 0.082 \\
\hline Site3 & $0.044(0.016)$ & $0.838(0.072)$ & 5.0 & 1.057 & 0.014 & 0.031 \\
\hline
\end{tabular}

$b$ is the linear coefficient, $a$ is the intercept, $C$ is the critical $P$ rate of fertilization that occurs at the intersection of the linear response curve and the plateau lines, $P$ represents plateau dry weight at the 6-leaf stage and plateau $P$ uptake at the 3- and 6-leaf stages, $R^{2}$ is the coefficient of determination, and MSE represents the mean square error. Values in parenthesis represent standard error of the estimates.

\section{Mehlich-3 P and P Saturation Indicators vs. Dry Matter Weight and P Uptake at Harvest}

The 11 sites selected for the 2-year study represented a wide range of $\mathrm{P}_{\mathrm{M} 3}$, $\mathrm{Pox}, \mathrm{Al}_{\mathrm{M} 3}, \mathrm{AlOx}, \mathrm{Fe}_{\mathrm{M} 3}$, and $\mathrm{FeOx}$ values (Table 1). The relationships between $\mathrm{P}_{\mathrm{M} 3}$, DPS, PSI and corn DMY and $\mathrm{P}$ uptake were described by a quadratic relationship (Figure 9). The quadratic relationships obtained in this study are significant, with $R^{2}$ values varying between 0.65 and 0.94 (Figures 9A,C). These relationships encompassed a range of $\mathrm{P}_{\mathrm{M} 3}$ between 60 and $200 \mathrm{mg} \mathrm{kg}^{-1}$, which is representative of high testing $\mathrm{P}$ soils of the coastal BC (Figures 9A,B), DPS between 14 and 38\% (Figures 9C,D), and PSI between 3 and 14\% (Figures 9E,F). However, site5 and site6 were not fitted by the functions. In addition, for the relationship between $\mathrm{P}_{\mathrm{M} 3}$ and $\mathrm{P}$ uptake, site4 and site7 were not fitted by the quadratic function (Figure 9B).

\section{DISCUSSION}

\section{The Effect of Starter P Fertilization on Growth of Young Silage Corn}

The linear-plus-plateau response models of DMY and P uptake to starter P obtained in 2018 confirm the well-established negative effects of low soil temperatures on performances of corn plants at early growth stages (3- and 6-leaf stages). In 2018, starter P was beneficial for corn growth early in the growing season in the three study sites. This positive effect coincided with low soil temperatures that prevailed early in the growing season between emergence and the 6-leaf stage (May 26 and June 26, 2018). Daily soil temperatures were below $19^{\circ} \mathrm{C}$ for 13 successive days, and
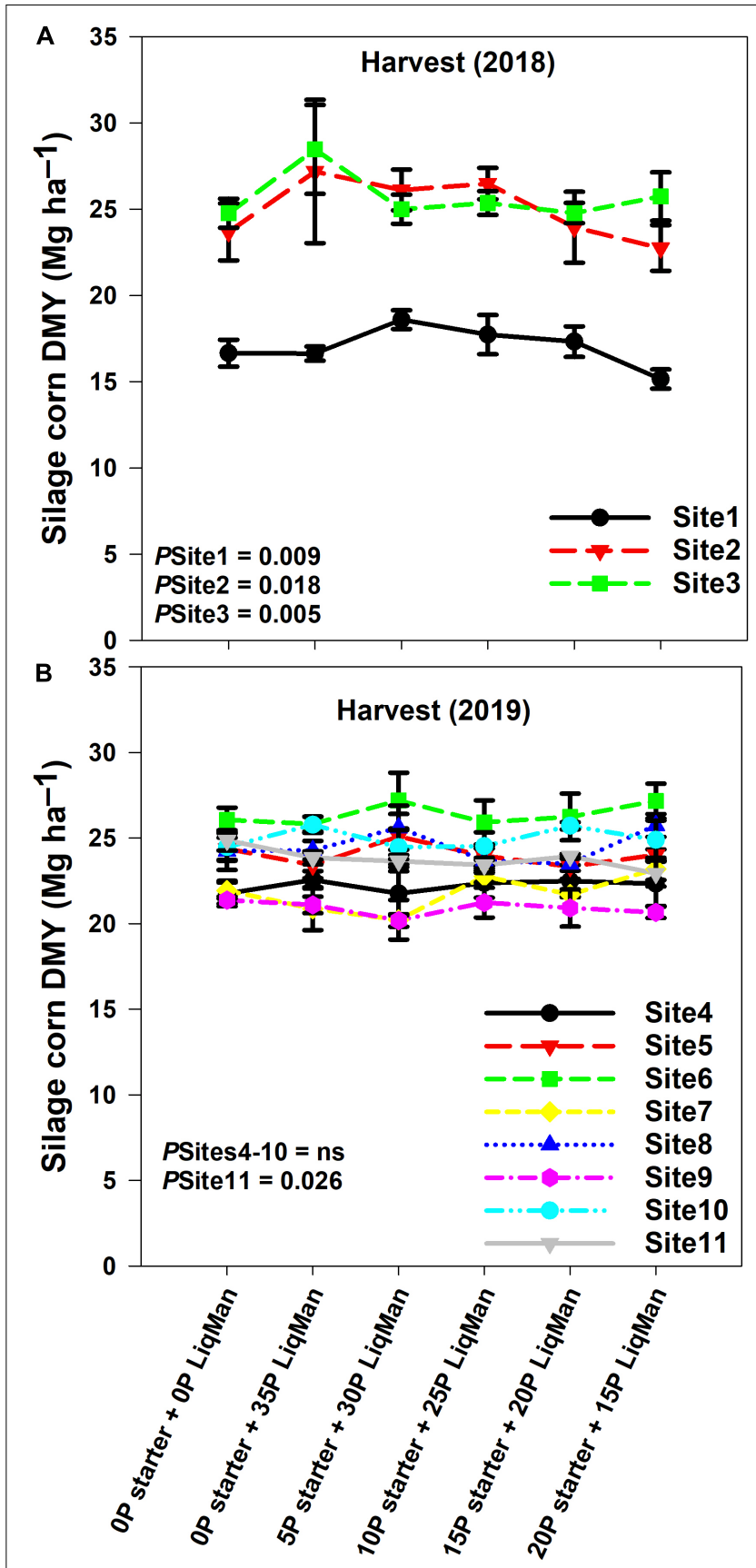

\section{Starter and manure $\mathbf{P}$ combinations}

FIGURE 4 | Corn dry matter yield (DMY) at harvest with application of starter $P$ rates and dairy manure across 11 sites [2018 (A) and 2019 (B)] in the Fraser Valley, BC. Dairy manure was applied at 6-leaf stage. Error bars represent standard deviations of the means.

soil temperatures as low as $17^{\circ} \mathrm{C}$ were recorded (Figure 1A). In contrast, in 2019, starter P had no significant effect on the 3- and 6-leaf stage corn plants in all eight study sites, probably because soil temperatures during the same period dropped below $19^{\circ} \mathrm{C}$ for only 5 successive days with a minimum of $18^{\circ} \mathrm{C}$ (Figure 1B). 


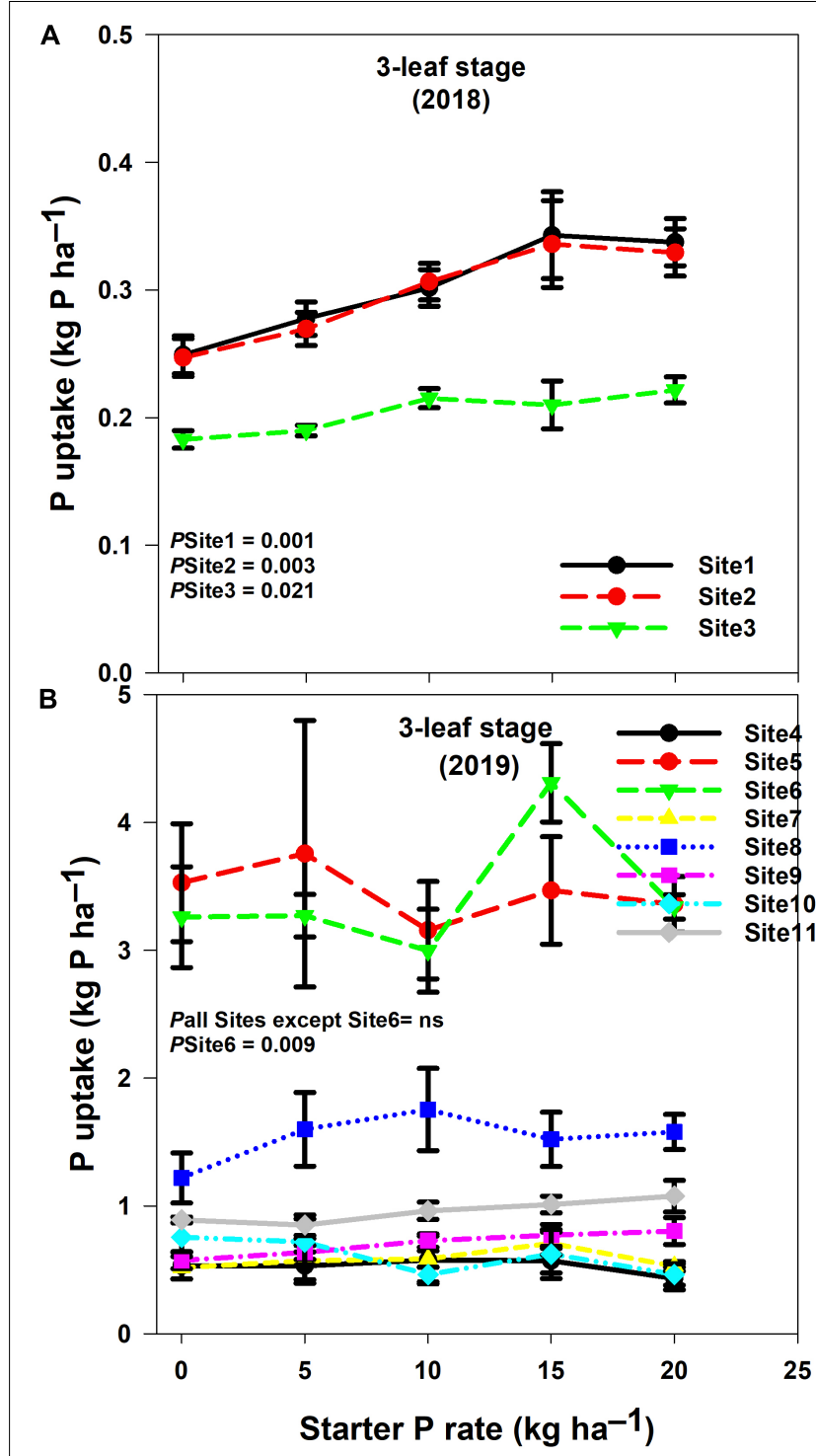

FIGURE 5 | Corn $\mathrm{P}$ uptake at 3-leaf stage with application of starter $\mathrm{P}$ rates and dairy manure across 11 sites [2018 (A) and 2019 (B)] in the Fraser Valley, BC. Dairy manure was applied at 6-leaf stage. Error bars represent standard deviations of the means.

Low soil temperatures early in the growing season reduce root growth and soil $\mathrm{P}$ availability even in high-P soils. One significant result of our study, however, is the critical starter $\mathrm{P}$ rates obtained from the linear-plus-plateau response models of DMY and $\mathrm{P}$ uptake to starter $\mathrm{P}$ at the 3- and 6-leaf stages. Overall, critical starter $\mathrm{P}$ rate was $5 \mathrm{~kg} \mathrm{P} \mathrm{ha}^{-1}$ at two sites and $7.5 \mathrm{~kg} \mathrm{P} \mathrm{ha}^{-1}$ at one site (Table 5). The $P$ values and mean square error (MSE) indicated that linear-plus-plateau models accurately predicted the response of DMY and P uptake of young corn plants to starter $\mathrm{P}$ at the 3- and 6-leaf stages in 2018. The critical starter $\mathrm{P}$ rates obtained in our study are in the range of those recommended in other areas. Starter P fertilizer rates for silage corn are 5 to $15 \mathrm{~kg} \mathrm{P} \mathrm{ha}{ }^{-1}$ in Ontario and Quebec (Preston, 2019) and 5 to

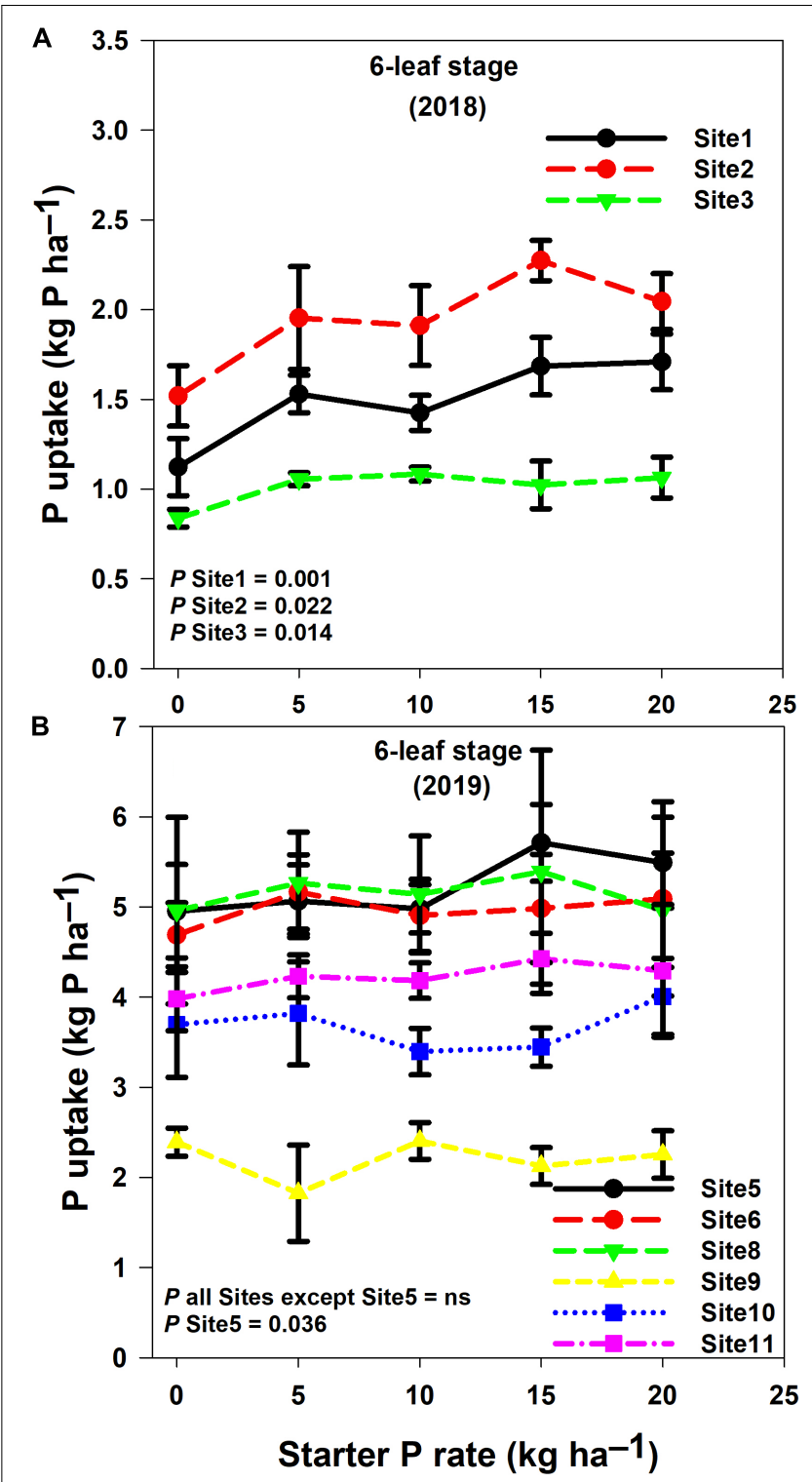

FIGURE 6 | Corn $P$ uptake at 6-leaf stage with application of starter $P$ rates and dairy manure across 11 sites [2018 (A) and 2019 (B)] in the Fraser Valley, BC. Dairy manure was applied at 6-leaf stage. Error bars represent standard deviations of the means.

$13 \mathrm{~kg} \mathrm{P} \mathrm{ha}^{-1}$ in the US (Jokela, 1992). In cool and moist coastal $\mathrm{BC}$, almost all silage corn is side-banded at approximately 30$40 \mathrm{~kg} \mathrm{P} \mathrm{ha}{ }^{-1}$, and most of the corn receives manure (Zhang et al., 2018). The critical starter $P$ rates obtained in our study are below local recommendations (British Columbia Ministry of Agriculture [BCMA], 2010). This indicates the need to refine and update recommendations for $\mathrm{P}$ fertilizer, particularly starter $\mathrm{P}$ fertilizer, for silage corn production in BC. Refining starter $\mathrm{P}$ fertilizer for silage corn will contribute to decreasing annual $\mathrm{P}$ inputs in this cropping system. A better match of $\mathrm{P}$ applications to silage corn needs will help to maintain or drawdown legacy $\mathrm{P}$ and reduce $\mathrm{P}$ losses to water sources. 


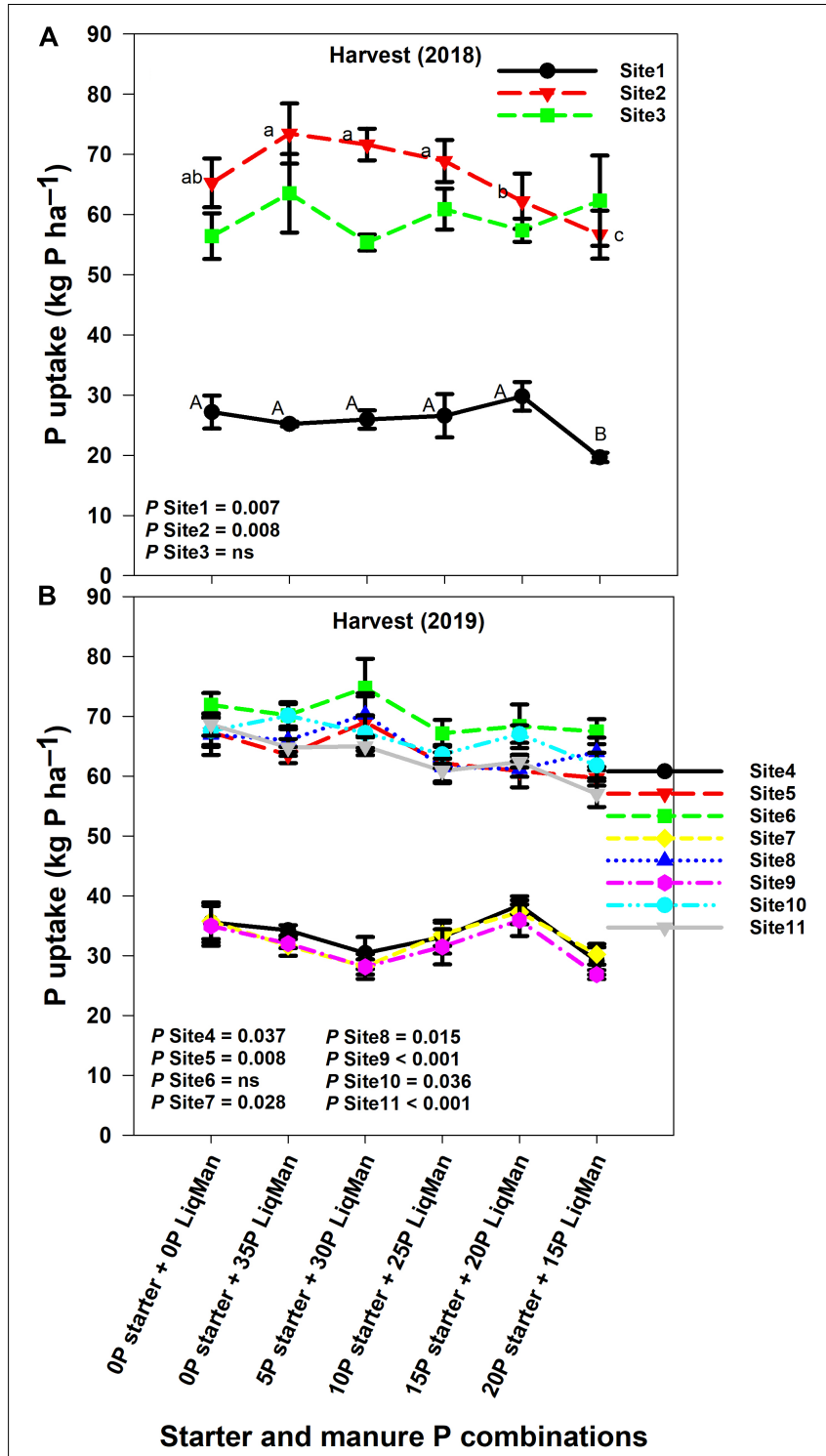

FIGURE 7 | Corn $\mathrm{P}$ uptake at harvest with application of starter $\mathrm{P}$ rates and dairy manure across 11 sites (2018 and 2019) in the Fraser Valley, BC. Dairy manure was applied at 6-leaf stage. Error bars represent standard deviations of the means.

\section{The Effects of Starter and Manure $P$ Additions on Corn Dry Matter Yield and P Uptake at Harvest}

Corn DMY values at harvest were in the range of those obtained by Zhang et al. (2018) in south coastal BC in a study investigating the effects of 11 year of different dairy manure fractions and mineral fertilizer on two consecutive silage corn productions with average DMY of $16.1 \mathrm{Mg} \mathrm{ha}^{-1}$ in 2015 and $22.7 \mathrm{Mg} \mathrm{ha}^{-1}$ in 2016. Our results are also in the range of those obtained by Ferreira and Teets (2017) in 2014 and 2015 at two commercial dairy farms located in Virginia. Our results are in the range of those obtained by Arriola et al. (2012) across several silage hybrids in
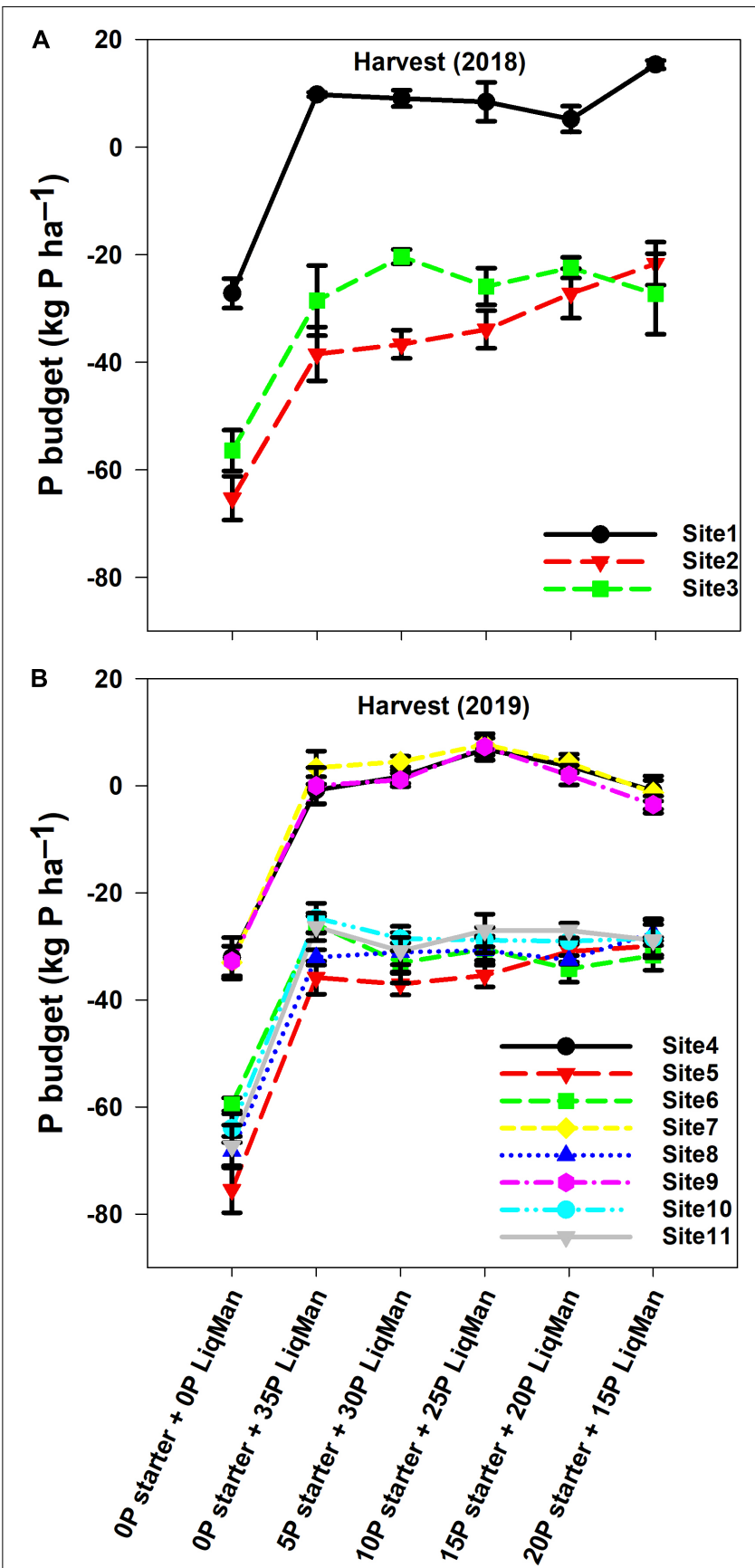

\section{Starter and manure $\mathbf{P}$ combinations}

FIGURE 8 | $\mathrm{P}$ budget at harvest with application of starter $\mathrm{P}$ rates and dairy manure across 11 sites [2018 (A) and 2019 (B)] in the Fraser Valley, BC. Dairy manure was applied at 6-leaf stage. Error bars represent standard deviations of the means.

Florida. In contrast, our results are higher than those of Jokela (1992), perhaps due to new and improved silage corn hybrids used in our study.

In our study, we were interested in understanding how a balanced $\mathrm{P}$ input including banded starter $\mathrm{P}$ fertilizer at planting 

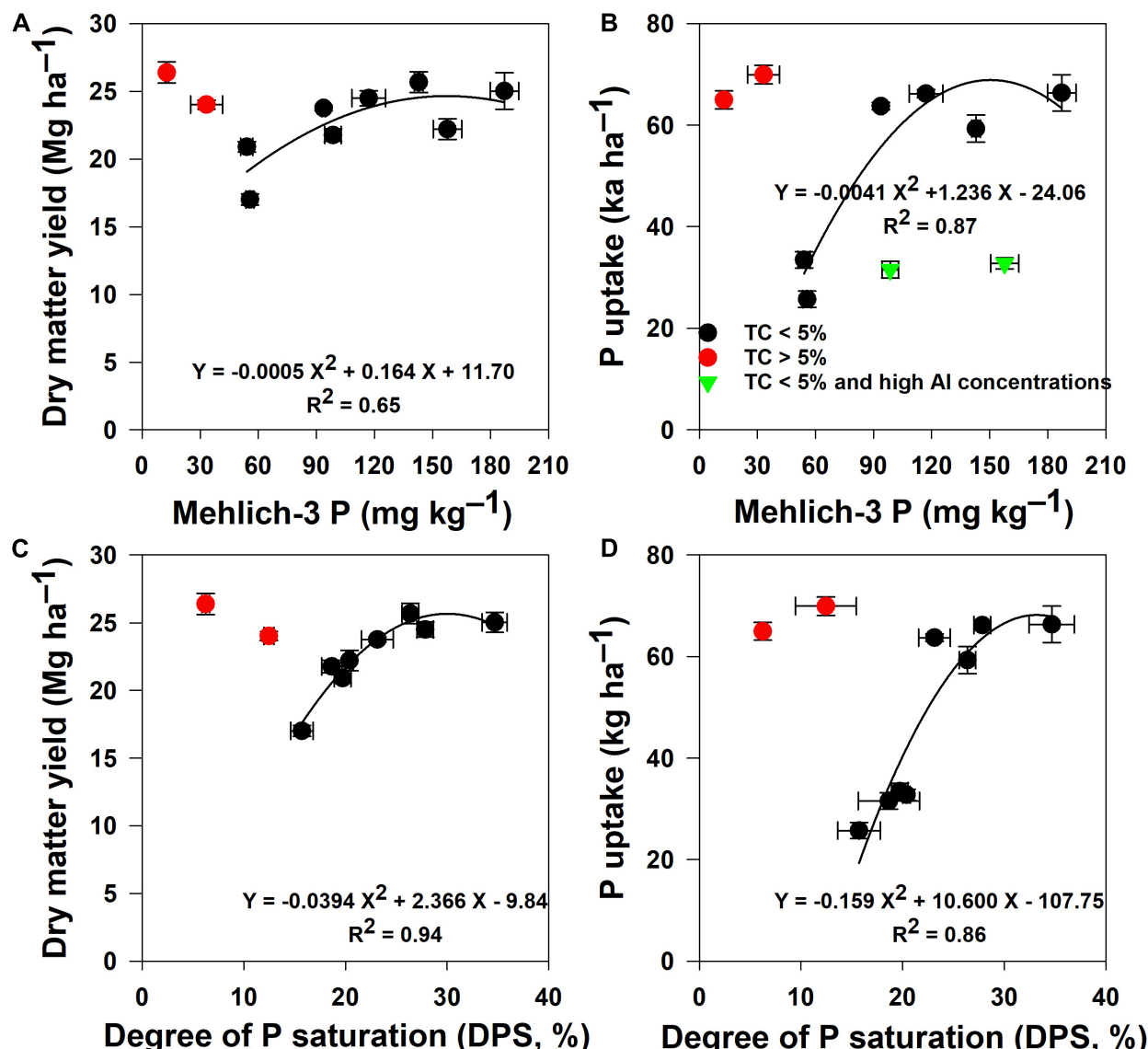

Degree of P saturation (DPS, \%)
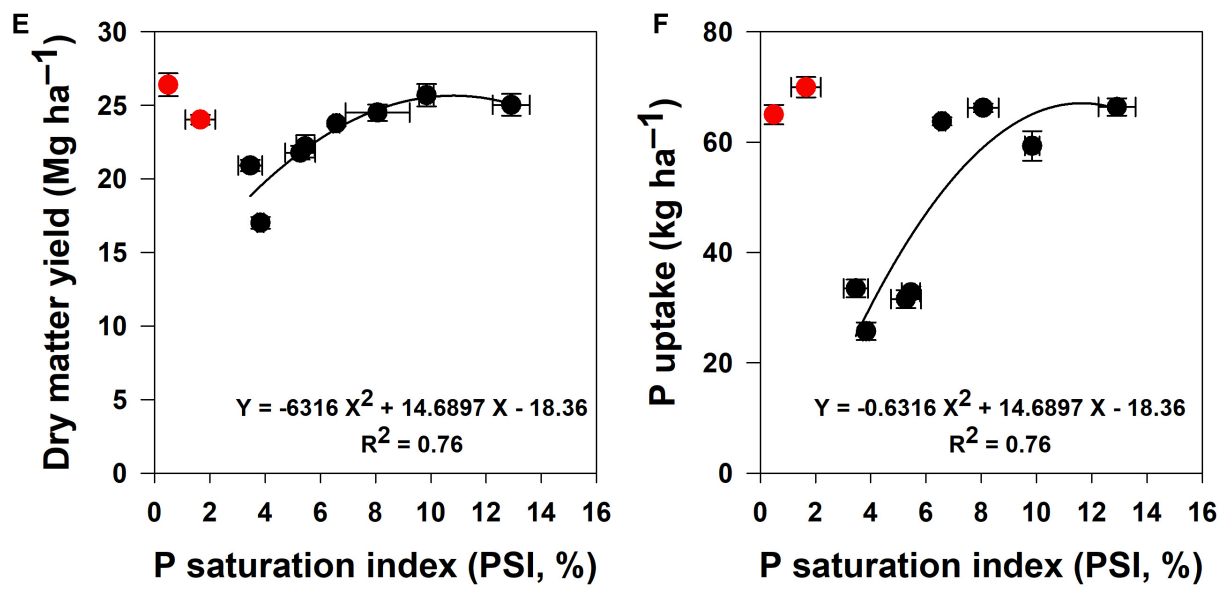

FIGURE 9 | Mehlich-3 P (A,B); Degree of P saturation (C,D); P saturation index (E,F) vs. Dry matter yield and P uptake at harvest with application of starter P rates and dairy manure across 11 sites in the Fraser Valley, BC. Dairy manure was applied at 6-leaf stage. Error bars represent standard deviations of the means.

and side-dressed manure $P$ at the 6-leaf stage affects silage corn DMY and P uptake at harvest. Our results show that in 4 out of the 11 study sites, there was a trend of high DMY at harvest with treatment combinations comprising low starter P rates $(<10 \mathrm{~kg} P$ $\left.\mathrm{ha}^{-1}\right)$ and high side-dressed manure $\mathrm{P}\left(>25 \mathrm{~kg} \mathrm{P} \mathrm{ha}^{-1}\right)$ additions at the 6-leaf stage (Figures 4A,B). Corn P uptake showed similar trends in 9 out of the 11 study sites (Figures 7A,B). The final DMY and $\mathrm{P}$ uptake values indicate that the effect of starter $\mathrm{P}$ observed at the 6-leaf stage in 2018 was not carryover through harvest. It is well-known that most crops take up only 10 to $20 \%$ of $\mathrm{P}$ fertilizer during the year of application. The decreasing trend of corn $\mathrm{P}$ uptake at harvest with treatments including high starter $\mathrm{P}$ rates indicates that part of $\mathrm{P}$ fertilizer was fixed by the soil and therefore was not readily available for plant uptake later in the growing season. Kowalenko (2005) showed that soils of coastal BC exhibit high $\mathrm{P}$ retention or fixation capacity. 
Zhang et al. (2018) also found that early plant response to starter $\mathrm{P}$ did not have a lasting effect on yield at final harvest even though starter $\mathrm{P}$ rate applied was $40 \mathrm{~kg} \mathrm{P} \mathrm{ha}^{-1}$. Mallarino et al. (1999) in several corn experiments in Iowa also found that early growth and nutrient uptake to banded $\mathrm{P}$ did not translate into higher yield. Jokela (1992) in a study conducted on 12 soils with contrasting $\mathrm{P}$ levels also found that when soil test $\mathrm{P}$ is medium or high, the likelihood of the carryover effect of starter $\mathrm{P}$ on silage corn yield through harvest is low.

The 6-leaf stage coincides with the beginning of rapid nutrient uptake by corn plants. In our study, the synchrony between the timing of manure $\mathrm{P}$ application and the growth stage corresponding to high nutrient demand enhanced the potential for greater corn $\mathrm{P}$ uptake (Figures $\mathbf{4 A}, \mathbf{B}$ ). In coastal BC where dairy manure is an important source of $\mathrm{P}$ and other nutrients for dairy farmers, management practices that include combinations of low starter $P$ rates and optimum rates of side-dressed manure $\mathrm{P}$ at the 6-leaf stage could be an alternative to current practices. The presence of other nutrients in dairy manure also contributed to a large extent to DM production and silage quality with optimum side-dressed manure $\mathrm{P}$ additions at the 6-leaf stage. In this study, nitrogen is the only element that was balanced among the treatment combinations (Table 3). Zhang et al. (2018) and other authors showed that interference in root $\mathrm{P}$ uptake with other nutrients such as zinc and calcium could occur in manure treated plots and result into lower $\mathrm{P}$ concentrations and $\mathrm{P}$ uptakes compared with control plots. We did not observe symptoms or other evidence of interference among nutrients on plant growth, probably because of the short-term nature of our study sites.

\section{Relationship Between Silage Corn Yield and $\mathbf{P}$ Saturation Indicators}

One important goal of this study is to improve our understanding of the mechanisms controlling $\mathrm{P}$ cycling in soils with high legacy $\mathrm{P}$ in coastal $\mathrm{BC}$ in order to reduce the risk of $\mathrm{P}$ losses to soils and water sources while building resilient cropping systems. In this study, we show that $\mathrm{P}_{\mathrm{M} 3}$, DPS and PSI are highly correlated with silage corn DMY and $\mathrm{P}$ uptake with $R^{2}$ values varying between 0.65 and 0.94 (Figure 9). These relationships encompassed a range of $\mathrm{P}_{\mathrm{M} 3}$ between 60 and $200 \mathrm{mg} \mathrm{kg}^{-1}$, which is representative of the high testing $\mathrm{P}$ soils of coastal BC (Figure 9A), DPS between 14 and 38\% (Figures 9A,B), and PSI between 3 and 14\% (Figure 9B). The significant relationship between PSI and DMY obtained in our study indicates that this proxy of DPS can be adapted for coastal BC soils as an agroenvironmental indicator to assess the risk of $\mathrm{P}$ losses. In the Netherlands, DPS $>25 \%$ indicates a high risk of $\mathrm{P}$ transport with runoff water (Breeuwsma and Silva, 1992). In Wallonia, Belgium, a study using 57 agricultural topsoil samples subject to diverse $\mathrm{P}$ management showed that DPS values between 20 and $30 \%$ corresponded to the agronomic optimum of soil P content (Renneson et al., 2015). In North America, the PSI has provided much-needed information to support environmental assessment at watershed, local, and provincial scales (Khiari et al., 2000; Sims et al., 2002; Benjannet et al., 2018).
Among the sites that were used for this study, two were not fitted by the quadratic functions for DMY and P uptake (site5 and site6). These sites were located in the same area and were characterized by $\mathrm{P}_{\mathrm{M} 3}$ values lower than $30 \mathrm{mg} \mathrm{kg}^{-1}$ and TC content greater that $7 \%$. Another contrasting behavior of these soils is that they yielded DMY in the high range at the 3-leaf stage $\left(0.80 \mathrm{Mg} \mathrm{ha}^{-1}\right)$, the 6 -leaf stage $\left(1.40 \mathrm{Mg} \mathrm{ha}^{-1}\right)$ and harvest (25 $\mathrm{Mg} \mathrm{ha}^{-1}$ ), which could not be supported by the low $\mathrm{P}_{\mathrm{M} 3}$ values (Figure 4B). It is possible that Mehlich-3 and Oxalate ammonium extracting solutions are not adapted for these soils with high organic matter content. It is also possible that the high organic matter content contributes to P supply to plants through mineralization throughout the growing season. Two other sites were also not fitted by the quadratic function for $\mathrm{P}_{\mathrm{M} 3}$ vs. $\mathrm{P}$ uptake (site4 and site7). The sites were located in the same area and were characterized by $\mathrm{P}_{\mathrm{M} 3}$ values of $155 \mathrm{mg} \mathrm{kg}^{-1}$ for site 4 and $90 \mathrm{mg} \mathrm{kg}^{-1}$ for site7. Even though the sites had high and very high soil test $\mathrm{P}, \mathrm{DMY}$ at the 3 -leaf stage (Figure $2 \mathbf{B}$ ) as well as $\mathrm{P}$ uptake at the 3-leaf stage (Figure 5B) and harvest (Figures 7A,B) were in the low range. These two sites were located on poorlydrained soils, and their reactive $\mathrm{Al}$ were much higher than the other sites, indicating a higher P fixation capacity as shown by their DPS and PSI, which are aggregated among sites with $\mathrm{P}_{\mathrm{M} 3}$ in the low range (Figures 9C-F). Additional sites with similar characteristics will be needed to derive a recommendation for starter $\mathrm{P}$ that is different from what is suggested in this study.

\section{Agronomic and Environmental Implications for Soils With High Legacy P}

The site-year dependence of young corn plant growth and the linear-plus-plateau response model to starter $\mathrm{P}$ fertilization have implications for $\mathrm{P}$ fertilizer recommendations for silage corn production in BC. As noted in sections above, fertilization management for silage corn in coastal BC includes dairy manure (liquid or solid) spreading at rates 30 to $50 \mathrm{Mg} \mathrm{ha}^{-1}$, usually in the spring just before moldboard plowing (British Columbia Ministry of Agriculture [BCMA], 2010). Phosphorus supplied by manure applications ranges from approximately 30 to $50 \mathrm{~kg}$ $\mathrm{P} \mathrm{ha}^{-1}$. In addition, starter fertilizer including $\mathrm{P}$ at rates 30 to $40 \mathrm{~kg} \mathrm{P} \mathrm{ha}{ }^{-1}$ is banded $5 \mathrm{~cm}$ to the side and $5 \mathrm{~cm}$ below the corn row with the planter. Therefore, the total annual $\mathrm{P}$ input in most fields ranged between 60 and $90 \mathrm{~kg} \mathrm{P} \mathrm{ha}{ }^{-1}$ for a crop that takes up approximately $35 \mathrm{~kg} \mathrm{P} \mathrm{ha}^{-1}$. The excess $\mathrm{P}$, on average $40 \mathrm{~kg} \mathrm{P} \mathrm{ha}^{-1}$ every year, accumulates in the soil and contributes to increasing the legacy soil $\mathrm{P}$. Our results demonstrate that $\mathrm{P}$ fertilizer recommendations for silage corn can be refined by decreasing starter $\mathrm{P}$ rates to 5.0 to $7.5 \mathrm{~kg} \mathrm{P} \mathrm{ha}{ }^{-1}$ without decreasing DMY at harvest. This result provides opportunities for the fertilizer industry in $\mathrm{BC}$ to prepare new starter fertilizer blends for silage corn production to address annual variations observed with soil temperatures early in the growing season (Figures 1A,B). These starter $\mathrm{P}$ rates will represent a cut of more than $75 \%$ of annual $\mathrm{P}$ input and could have a positive incidence on farmers' production costs and the dairy industry as a whole while protecting the environment. In southern BC, dairy farmers grow silage corn 
for five consecutive years followed by another five consecutive years of forage grass. It is crucial to understand whether annual applications of critical starter $\mathrm{P}$ rates are necessary and how they affect the growth of young silage corn plants in these types of rotation systems. Future studies are therefore needed to test the stability of annual applications of critical starter $\mathrm{P}$ rates during the silage corn phase. This knowledge will be useful to provide recommendations specifically tailored for dairy farmers and will contribute to better managing legacy soil $\mathrm{P}$ in silage corn and forage grass rotation systems in southern BC.

So far, most private laboratories in coastal BC use the Kelowna or modified Kelowna methods to assess the status of soil test $\mathrm{P}$ for $\mathrm{P}$ fertilizer recommendations. Our results show that the Mehlich3 method, which is widely used in acidic to near-neutral soils in North America including Canada, can be used on the soils of coastal BC. Use of the Mehlich-3 method offers the opportunity to assess other cations such as $\mathrm{Al}$ and $\mathrm{Fe}$ and therefore make it possible to adapt a PSI for BC soils (Khiari et al., 2000; Sims et al., 2002; Benjannet et al., 2018). We showed that $\mathrm{P}_{\mathrm{M} 3}$, DPS and PSI were all closely related to silage corn DMY and P uptake across 11 soils with a wide range of soil test $P$ levels. Finally, future works including additional soils with contrasting properties will be needed to identify environmental $\mathrm{P}$ risk classes at the scale of coastal BC, Canada.

\section{CONCLUSION}

Silage corn DMY was affected by starter P fertilizer at the 6-leaf stage in one out of two seasons, and this response coincided with 13 consecutive days of low soil temperatures. Our results show that the response of DMY to starter $\mathrm{P}$ is described by a linear-plus-plateau model with critical starter $\mathrm{P}$ rate at 5.0 and $7.5 \mathrm{~kg} \mathrm{P} \mathrm{ha}{ }^{-1}$. Our results also show that in 4 out of the 11 study sites, there was a trend of high DMY at harvest with treatment combinations comprising low starter $\mathrm{P}$ rates and high side-dressed manure $\mathrm{P}$ additions at the 6-leaf stage. Thus, the effect of starter P fertilizer observed at early growth stages was not carryover through harvest. It appears that when high amounts of $\mathrm{P}$ fertilizers are banded as starter $\mathrm{P}\left(30\right.$ to $\left.40 \mathrm{~kg} \mathrm{P} \mathrm{ha}^{-1}\right)$ to promote the growth of young corn plants early in the season when soil temperatures are still low, part of this $\mathrm{P}$ is fixed and

\section{REFERENCES}

Arriola, K. G., Kim, S. C., Huisden, C. M., and Adesogan, A. T. (2012). Stay-green ranking and maturity of corn hybrids: 1 . Effects on dry matter yield, nutritional value, fermentation characteristics, and aerobic stability of silage hybrids in Florida. J. Dairy Sci. 95, 964-974. doi: 10.3168/jds.2011-4524

Benjannet, R., Khiari, L., Nyiraneza, J., Thompson, B., He, J., Geng, X., et al. (2018). Identifying environmental phosphorus risk classes at the scale of Prince Edward Island, Canada. Can. J. Soil Sci. 98, 317-329. doi: 10.1139/cjss-2017-0076

Bittman, S., Kowalenko, G. C., Hunt, D. E., Forge, T. A., and Wu, X. (2006). Starter phosphorus and broadcast nutrients on corn with contrasting colonization by mycorrhizae. Agron. J. 98, 394-401. doi: 10.2134/agronj2005.0093

Bittman, S., Sheppard, S. C., Poon, D., and Hunt, D. E. (2017). Phosphorus flows in a peri-urban region with intensive food production: a case study. J. Environ. Manag. 187, 286-297. doi: 10.1016/j.jenvman.2016.11.040 therefore is not readily available for corn $\mathrm{P}$ uptake later in the growing season. This fixed $\mathrm{P}$ contributes to increased legacy soil $\mathrm{P}$ and the risk of $\mathrm{P}$ losses to water sources. Our results also highlighted the fact that $\mathrm{P}_{\mathrm{M} 3}$, DPS and PSI are highly correlated with silage corn DMY and P uptake and therefore indicate that PSI as a proxy of DPS can be adapted for coastal BC soils as an indicator of the risk of $\mathrm{P}$ losses.

\section{DATA AVAILABILITY STATEMENT}

The datasets generated for this study are available on request to the corresponding author.

\section{AUTHOR CONTRIBUTIONS}

AM conceived the idea and wrote the manuscript. CB and AM designed the methodology and planned all the field activities on the 11 sites, and analyzed the data and prepared the graphs and tables. CL, SK, YL, SY, CB, and AM established the experiments, applied the treatments of starter $\mathrm{P}$ and manure $\mathrm{P}$, maintained all the sites, collected all the soil and plant samples and performed all the laboratory analyses, and contributed to the study and gave final approval for the manuscript.

\section{FUNDING}

AM thanks Agriculture and Agri-Food Canada for funding this work through an A-Base program (Project ID: J-002266 - Solutions for carryover of legacy $\mathrm{P}$ in the Fraser Valley and Hullcar Valley).

\section{ACKNOWLEDGMENTS}

We thank Duncan Reid from Terralink, Inc. for his help in finding dairy farmers in Agassiz and Rosedale who agreed to share their land for this research. We thank Jessica Stoeckli and Deen Babuin from the Agassiz RDC research support unit for their assistance with analyses using ICP.

Bordoli, J. M., and Mallarino, A. P. (1998). Deep and shallow banding of phosphorus and potassium as alternatives to broadcast fertilization for notill corn. Agron. J. 90, 27-33. doi: 10.2134/agronj1998.0002196200900001 $0006 x$

Breeuwsma, A., and Silva, S. (1992). Phosphorus Fertilization And Environmental Effects in the Netherlands and the Po Region (Italy). Report No. 57. Wageningen: DLO The Winand Staring Centre.

British Columbia Ministry of Agriculture [BCMA] (2010). Nutrient Management Reference Guide, eds D. Poon, and O. Schmidt (Columbia: BCMA).

British Columbia Ministry of Environment (2006). Water Quality, Water Management Branch Ministry of Environment. Victoria: British Columbia Ministry of Environment.

Cerrato, M. E., and Blackmer, A. M. (1990). Comparison of models for describing; corn yield response to nitrogen fertilizer. Agron. J. 82, 138-143. doi: 10.2134/ agronj1990.00021962008200010030x 
Ferreira, G., and Teets, C. L. (2017). Effect of planting density on yield, nutritional quality, and ruminal in vitro digestibility of corn for silage grown under on-farm conditions. PAS 33, 420-425. doi: 10.15232/pas.2017-01621

Hendershot, W. H., Lalande, H., and Duquette, M. (1993). "Ion exchange and exchangeable cations, in Soil Sampling and Methods of Analysis eds. M. R. Carter, and E. G. Gregorich (Boca Raton, FL: Lewis Publishers), 183-205.

Jokela, W. E. (1992). Effect of starter fertilizer on corn silage yields on medium and high fertility soils. J. Prod. Agric. 5, 233-237.

Khiari, L., Parent, L. E., Pellerin, A., Alimi, A. R. A., Tremblay, C., Simard, R. R., et al. (2000). An agri-environmental phosphorus saturation index for acid coarse-textured soils. J. Environ. Qual. 29, 1561-1567. doi: 10.2134/jeq2000. $00472425002900050024 \mathrm{x}$

Kowalenko, C. G. (2005). Binding of inorganic sulphate and phosphate in humid-climate soils measured using column leaching, equilibration and extraction methods. Can. J. Soil Sci. 85, 599-610. doi: 10.4141/ s04-068

Kowalenko, C. G., and Babuin, D. (2014). Use of lithium metaborate to determine total phosphorus and other element concentrations in soil, plant, and related materials. Commun. Soil Sci. Plant Anal. 45, 15-28. doi: 10.1080/00103624. 2013.848884

Kowalenko, G. C., Schmidt, O., Kenney, E., Neilsen, D., and Poon, D. (2007). Okanagan Agricultural Soil Study 2007. A Survey Of The Chemical And Physical Properties Of Agricultural Soils Of The Okanagan And Similkameen Valleys In Relation To Agronomic And Environmental Concerns. Available online at: https://www2.gov.bc.ca/assets/gov/farming-natural-resources-and-industry/ agriculture-and-seafood/agricultural-land-and-environment/environmentalfarm-planning/okanagan_soil_study_report_2007.pdf (accessed December 20, 2019).

Malhi, S. S., Zentner, R. P., and Heier, K. (2001). Banding increases effectiveness of fertilizer P for alfalfa production. Nutr. Cyc. Agroecosys. 59, 1-11.

Mallarino, A. P., Bordoli, J. M., and Borges, R. (1999). Phosphorus and potassium placement effects on early growth and nutrient uptake of No-Till corn and relationships with grain yield. Agron. J. 91, 37-45. doi: 10.2134/agronj1999. $00021962009100010007 x$

Mehlich, A. (1984). Mehlich 3 soil test extractant: a modification of Mehlich 2 extractant. Commun. Soil Sci. Plant Anal. 15, 1409-1416. doi: 10.1080/ 00103628409367568

Messiga, A. J., Ziadi, N., Bélanger, G., and Morel, C. (2013). Soil nutrients and other major properties in grassland fertilized with nitrogen and phosphorus. Soil Sci. Soc. Am. J. 77, 643-652. doi: 10.2136/sssaj2012.0178

Pellerin, A., Parent, L. -É, Fortin, J., Tremblay, C., Khiari, L., and Giroux, M. (2006). Environmental Mehlich-III soil phosphorus saturation indices for Quebec acid to near neutral mineral soils varying in texture and genesis. Can. J. Soil Sci. 86, 711-723. doi: $10.4141 / \mathrm{s} 05-070$
Preston, C. L., Ruiz Diaz, D. A., and Mengel, D. B. (2019). Corn response to longterm phosphorus fertilizer application rate and placement with strip-tillage. Agron. J. 111, 841-850. doi: 10.2134/agronj2017.07.0422

Randall, G. W., and Hoeft, R. G. (1988). Placement methods for improved efficiency of $\mathrm{P}$ and $\mathrm{K}$ fertilizers: a review. J. Prod. Agric. 1, 70-78.

Renneson, M., Van denberghe, C. J., Dufey, J. M., Marcoen, L. B., and Colinet, G. (2015). Degree of phosphorus saturation in agricultural loamy soils with a near-neutral pH. Eur. J. Soil Sci. 66, 33-41. doi: 10.1111/ejss.12207

Ross, G. J., and Wang, C. (1993). "Extractable Al, Fe, Mn, and Si," in Soil Sampling and Methods Of Analysis, 1st Edn, ed. M. R. Carter (Boca Raton, FL: Lewis Publishers).

SAS Institute (2010). SAS User's Guide: Statistics, Version 9, 3rd Edn. Cary, NC: SAS Institute Inc.

Sims, J. T., Maguire, R. O., Leytem, A. B., Gartley, K. L., and Pautler, M. C. (2002). Evaluation of Mehlich-3 as an agri-environmental soil phosphorus test for the Mid-Atlantic United States of America. Soil Sci. Soc. Am. J. 66, 2016-2032. doi: $10.2136 /$ sssaj2002.2016

Soil Survey Staff (2014). Soil Survey Manual. Soil Conservation Service. Washington, DC: USDA.

van Bochove, E., Theriault, G., Denault, J., Dechmi, F., Allaire, S. E., and Rousseau, A. N. (2012). Risk of phosphorus desorption from canadian agricultural land: 25-year temporal trend. J. Environ. Qual. 41, 1402-1412. doi: 10.2134/jeq2011. 0307

Vetsch, J. A., and Randall, G. W. (2002). Corn production as affected by tillage system and starter fertilizer. Agron. J. 94, 532-540. doi: 10.2134/agronj2002. 5320

Wolkowski, R. P. (2000). Row-placed fertilizer for maize grown with an in-row crop residue management system in southern Wisconsin. Soil Tillage Res. 54, 55-62. doi: 10.1016/s0167-1987(99)00114-2

Zhang, H., Bittman, S., Hunt, D. E., Bounaix, F., and Messiga, A. J. (2018). Availability of phosphorus after long-term whole and separated slurry application to perennial grass prior to corn silage. J. Environ. Qual. 47, 893-901. doi: $10.2134 /$ jeq2017.12.0466

Conflict of Interest: The authors declare that the research was conducted in the absence of any commercial or financial relationships that could be construed as a potential conflict of interest.

Copyright (c) 2020 Her Majesty the Queen in right of Canada. This is an open-access article distributed under the terms of the Creative Commons Attribution License (CC BY). The use, distribution or reproduction in other forums is permitted, provided the original author(s) and the copyright owner(s) are credited and that the original publication in this journal is cited, in accordance with accepted academic practice. No use, distribution or reproduction is permitted which does not comply with these terms. 